\title{
West Africa Extreme Rainfall Events and Large-Scale Ocean Surface and Atmospheric Conditions in the Tropical Atlantic
}

\author{
S. Ta, ${ }^{1}$ K. Y. Kouadio, ${ }^{1}$ K. E. Ali, ${ }^{1,2}$ E. Toualy, ${ }^{1}$ A. Aman, ${ }^{1}$ and F. Yoroba ${ }^{1}$ \\ ${ }^{1}$ Laboratory of Atmospheric Physics and Fluid Mechanics, University FHB of Cocody-Abidjan, 22 BP 582, Abidjan 22, Côte d'Ivoire \\ ${ }^{2}$ Institut National Polytechnique Félix Houphouët Boigny de Yamoussoukro, BP 1093, Yamoussoukro, Côte d'Ivoire \\ Correspondence should be addressed to S. Ta; biladjisamuelta@outlook.com
}

Received 6 April 2016; Revised 11 June 2016; Accepted 26 June 2016

Academic Editor: Anthony R. Lupo

Copyright (c) $2016 \mathrm{~S}$. Ta et al. This is an open access article distributed under the Creative Commons Attribution License, which permits unrestricted use, distribution, and reproduction in any medium, provided the original work is properly cited.

\begin{abstract}
Based on daily precipitation from the Global Precipitation Climatology Project (GPCP) data during April-October of the 19972014 period, the daily extreme rainfall trends and variability over West Africa are characterized using 90th-percentile threshold at each grid point. The contribution of the extreme rainfall amount reaches $\sim 50-90 \%$ in the northern region while it is $\sim 30-$ $50 \%$ in the south. The yearly cumulated extreme rainfall amount indicates significant and negative trends in the $6^{\circ} \mathrm{N}-12^{\circ} \mathrm{N} ; 6^{\circ} \mathrm{N}-$ $12^{\circ} \mathrm{N} ; 17^{\circ} \mathrm{W}-10^{\circ} \mathrm{W}$ and $4^{\circ} \mathrm{N}-7^{\circ} \mathrm{N} ; 4^{\circ} \mathrm{N}-7^{\circ} \mathrm{N} ; 6^{\circ} \mathrm{E}-10^{\circ} \mathrm{E} 4^{\circ} \mathrm{N}-7^{\circ} \mathrm{N} ; 6^{\circ} \mathrm{E}-10^{\circ} \mathrm{E} 4^{\circ} \mathrm{N}-7^{\circ} \mathrm{N} ; 6^{\circ} \mathrm{E}-10^{\circ} \mathrm{E}$ domains, while the number of days exhibits nonsignificant trends over West Africa. The empirical orthogonal functions performed on the standardized anomalies show four variability modes that include all West Africa with a focus on the Sahelian region, the eastern region including the south of Nigeria, the western part including Guinea, Sierra Leone, Liberia, and Guinea-Bissau, and finally a small region at the coast of Ghana and Togo. These four modes are influenced differently by the large-scale ocean surface and atmospheric conditions in the tropical Atlantic. The results are applicable in planning the risks associated with these climate hazards, particularly on water resource management and civil defense.
\end{abstract}

\section{Introduction}

Rainfall is one of the most usable weather parameters that allows determining climate variability, particularly in West Africa $[1,2]$. Its quantification is a great concern in the tropics as it plays a significant role in hydrological and climate studies. Furthermore, the social and economic development of West Africa countries is strongly linked to agricultural and water resources [3]. In the last several decades, alteration of periods with extreme rainfall events with dry conditions has led to a succession of flood/drought years [4]. These extreme events constitute the primary impact of the climate change on society [5] since their frequencies have more impact compared to changes in mean climate [6].

The spatiotemporal distribution of the extreme rainfall events is not homogenous in West Africa. They can cause flooding or drought that have negative impacts by increasing environmental disasters. For example, rainfall irregularity leads to disastrous consequences if a drought situation persists. That was the case in the early 1970s during which the Sahel region experienced severe drought and devastating famine [7]. On the other hand, flood periods can have dramatic consequences in poor countries of West Africa. Such situation was observed in 1994 when the runoff of the Bagré Dam in Burkina Faso reached $2050 \mathrm{~m}^{3} \mathrm{~s}^{-1}$ instead of the initial project runoff of $1520 \mathrm{~m}^{3} \mathrm{~s}^{-1}$ [8]. Another flooding episode ( $>300 \mathrm{~mm}$ of rainfall amount) occurred during August 31 to September 01, 2009, in Ouagadougou (Burkina Faso) where it caused serious damage due to the overflowing of drainage channels and the dam. Consequently traffic was disrupted, houses were destroyed, and patients from Yalgado Ouédraogo Hospital were evacuated (http://reliefweb.int/ disaster/fl-2009-000172-bfa). The southern region of West Africa also has experienced social and economic impacts due to flooding, as, for instance, the episodes that caused many deaths in Abidjan (Côte d'Ivoire, 39 deaths in 2014 and 16 deaths on June 22, 2015; see http://www.rfi.fr/afrique/ 20150621-cote-ivoire-bilan-victimes-intemperies-pluies-abidjan). 


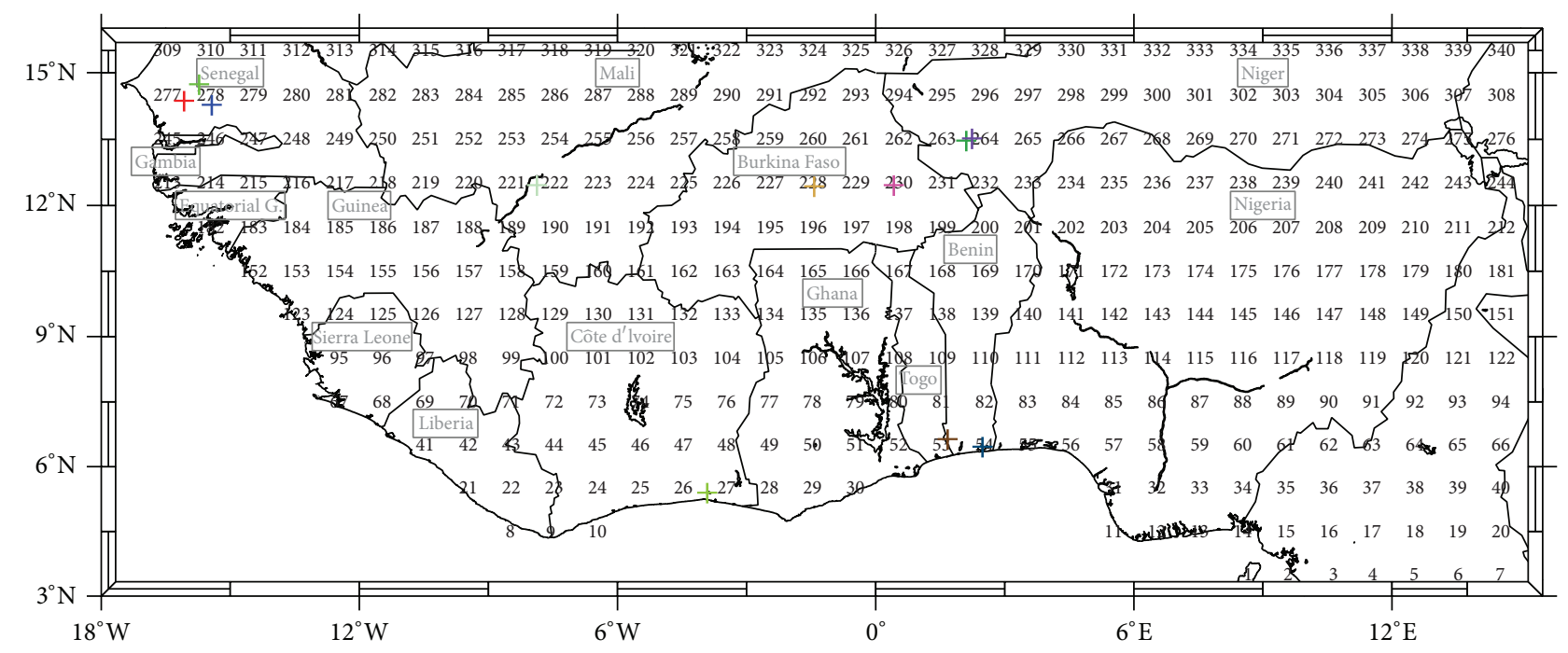

$\begin{array}{ll}+212-1-02 / 07 / 2014 & +251-1-15 / 05 / 2013 \\ +58-3-28 / 08 / 2013 & +171-1-17 / 05 / 2013 \\ +144-1-26 / 08 / 2013 & +119-1-18 / 08 / 2012 \\ +135-1-26 / 08 / 2013 & +87-3-19 / 08 / 2012 \\ +121-1-15 / 08 / 2013 & +263-1-01 / 09 / 2009 \\ +166-1-13 / 08 / 2013 & \end{array}$

Figure 1: Example of the total amount of rainfall at different locations (represented by signs) in West Africa and the number of days during which it occurs for three years. The legend at the bottom-left shows the rainfall amount (in mm, first number), the number of days of rainfall during which it occurred (second number), and the first date when this event begins (the date). The numbers at the continent represent each grid used for the analysis. Countries are also mentioned by their limits.

To illustrate the spatial distribution of extreme rainfall events, Figure 1 shows the locations of extreme rainfall events, the total amount of rainfall accumulated, and their duration. Updated floods and their negative consequences in West Africa can also be visualized through the ReliefWeb website (http://reliefweb.int/topics/floods) of the United Nations Office for the Coordination of Humanitarian Affairs (OCHA).

Many authors have contributed to the understanding and the behavior knowledge of the extreme daily rainfall. Many studies have contributed to understanding the behavior of extreme daily rainfall. For example, Giannini et al. [9] discussed intensification of an event in Senegal which is one of the westernmost countries of West Africa, while New et al. [10] observed a positive trend of rainfall for five stations in Gambia and Nigeria. According to Goula et al. [11], the drier trend in the frequency of extreme daily rainfall is not observed in all Côte d'Ivoire. All the results above highlight different spatial evolution of the extreme daily rainfall. This is in agreement with the result of six global circulation models (ECHAM4.5, Hadley Centre Atmospheric Model (HadAM3), CSIRO Mk2, GFDL 2.1, MRI, and MIROC) forced by the SRES-A2 scenario for 2080-2099, which showed strong drying over the center of the Sahel with a subsequent drop of extreme rainfall days [12]. Wetter trends were also found along the coast of the Gulf of Guinea, resulting in a $20 \%$ increase in high rainfall events.
The disastrous consequences of these extreme events and scenarios in the West African countries make the variability and trends of extreme rainfall essentials for planning the risks associated with these climate hazards, particularly on water resources management and civil defense. Even if the extreme events in West Africa are documented $[13,14]$, only a limited number of studies were done on only a few countries or a few meteorological stations $[11,15,16]$. Then, additional studies covering a greater geographical area with a higher spatial distribution of data are warranted. Thus the main purpose of this study is to analyse the variability and the trends of this extreme daily rainfall over West Africa. It will also allow identifying the extreme rainfall variability modes and their relationships with large-scale ocean surface and atmospheric conditions.

Section 2 presents the dataset and the method used. In Section 3, analysis of the extreme rainfall trends and variability modes are studied. This section also outlines the relationships between large-scale ocean surface and atmospheric conditions and the variability modes found. Finally, a conclusion is provided in the last section.

\section{Data and Methods}

The West Africa area $\left(18^{\circ} \mathrm{W}-15^{\circ} \mathrm{E} ; 3^{\circ} \mathrm{N}-16^{\circ} \mathrm{N}\right)$ is subdivided into three latitudinal zones which include the Sahel in the north $\left(11^{\circ} \mathrm{N}-15^{\circ} \mathrm{N}\right)$ and two zones further south named the 
Sudano-Guinean zone $\left(8^{\circ} \mathrm{N}-11^{\circ} \mathrm{N}\right)$ and the Guinea coast $\left(5^{\circ} \mathrm{N}-8^{\circ} \mathrm{N}\right)$ that borders the tropical Atlantic Ocean [17]. The unimodal rainfall regime of the Sahelian zone is centered in August with an annual rainfall amount ranging between 400 and $600 \mathrm{~mm}$. The bimodal rainfall regimes of the SudanoGuinean zone and Guinea coast are centered in June and October which represent the peaks of the great and minor rainy season, respectively. The annual rainfall amounts reach $900-1200 \mathrm{~mm}$ at the Sudano-Guinean zone while it is ranging between 1500 and $2000 \mathrm{~mm}$ at the Guinea coast. The rainfall regimes follow the seasonal migration of the intertropical convergence zone (ITCZ) and are also associated with the northward penetration of the monsoon flux on the continent [18]. The influence of these mechanisms on the climate zones depends on the months during the seasonal cycle and could vary in particular years [19]. Finally, an analysis of extreme rainfall events for the entire domain, including the characteristics of each country for every grid point, is presented.

This analysis is undertaken by using daily precipitation data provided by the Global Precipitation Climatology Project (GPCP) [20] from April to October. The period includes the rainfall seasons of all West Africa countries $\left(18^{\circ} \mathrm{W}-15^{\circ} \mathrm{E} ; 3^{\circ} \mathrm{N}-16^{\circ} \mathrm{N}\right)$. The GPCP rainfall is extracted on a $1^{\circ} \times 1^{\circ}$ regular grid in this season from 1997 to 2014 (i.e., a total of 3852 days) over the study area. This dataset is deduced from blending of in situ observations and microwave measurements carried out by various geostationary satellites. These gridded data will also allow identifying variability modes of the extreme rainfall in West Africa.

An intense precipitation event is defined as the exceedance of a threshold that corresponds to the daily rainfall amount exceeding a given value during the study period [21]. The extreme value can be defined by using arbitrary thresholds $[22,23]$ or by using percentiles that are statistical quantities [23-25]. For this study, there is no single precipitation threshold over the entire region above which daily precipitation can be considered as extreme, since rainfall periods could differ according to each country. Therefore, each grid is numbered (see Figure 1) and the extreme daily precipitation is forecasted on all the chronological series (i.e., 3852 values) associated with this grid. The gridded 90th-percentile value of the series is used as the threshold for extreme daily rainfall to take into account the specificity of the precipitation at each grid point. Sarr and Lona [26] found that this statistical quantity allowed detecting flooding episodes associated with extreme rainfall in Burkina Faso. For each grid, any daily rainfall amount is considered as extreme if it is greater than the threshold. Getting the extreme daily values, the next step is the statistical analysis of the extreme rainfall variability by using the linear trends and empirical orthogonal functions (Eof) on the study area.

The relationship between extreme rainfall and largescale ocean surface and atmospheric conditions is established by using the sea surface temperature (SST), horizontal and vertical winds, specific humidity, and latent heat flux. The sea surface conditions are documented for the tropical Atlantic using Reynolds' monthly SST data
[27] extracted from the IRI/LDEO Climate Data Library (http://iridl.ldeo.columbia.edu/). These data are reported on a $1^{\circ} \times 1^{\circ}$ grid for 1997-2014. Horizontal and vertical wind fields, specific humidity, and latent heat flux are extracted from the National Center for Environmental Prediction-National Center for Atmospheric Research (NCEP-NCAR) reanalysis dataset [28] for the same periods (1997-2014). Monthly data are reported on a $2.5^{\circ} \times 2.5^{\circ}$ grid, with 17 pressure levels from $1000 \mathrm{hPa}$ to $10 \mathrm{hPa}$ for horizontal and vertical wind and 8 pressure levels from $1000 \mathrm{hPa}$ to $10 \mathrm{hPa}$ for specific humidity. Moisture flux at $700 \mathrm{hPa}$ is calculated from the product of the wind and the specific humidity.

\section{Results}

3.1. Threshold and the Contribution of Extreme Rainfall. The spatial distribution of the 90th-percentile values is presented on Figure 2. The values are used as the thresholds of a daily extreme precipitation (Figure 2(a)). The ratio pattern of the total number of extreme precipitation days (Figure 2(b)) and the cumulated extreme rainfall amount versus the accumulated amount of the 3852 days (Figure 2(c)) are also plotted to underline the contribution of this phenomenon. The thresholds (see Figure 2(a)) decrease from the southern coastal areas $(\sim 10-20 \mathrm{~mm})$ bordering the tropical Atlantic to the northern ones located in the Sahelian regions $(\sim 5-$ $10 \mathrm{~mm}$ ). Particularly, they seem to define areas of high values as, for instance, in the regions $6^{\circ} \mathrm{N}-12^{\circ} \mathrm{N} ; 17^{\circ} \mathrm{W}-10^{\circ} \mathrm{W}$ and $4^{\circ} \mathrm{N}-7^{\circ} \mathrm{N} ; 6^{\circ} \mathrm{E}-10^{\circ} \mathrm{E}$ where the maximum reaches $\sim 25 \mathrm{~mm}$. These two last zones are known to be the rainiest areas and to have the longest rainy season in West Africa [29]. Low values of the threshold $(\sim 10 \mathrm{~mm})$ are also observed along the littoral of Côte d'Ivoire, Ghana, and Togo.

The ratio pattern of the total number of extreme rainy days (Figure 2(b)) during the whole period (1997-2014) and the contribution of extreme rainfall amount (Figure 2(c)) above $12^{\circ} \mathrm{N}$ are practically two times higher than those below this latitude. The extreme rainy days in the southern region of West Africa contribute to $30-50 \%$ of the rainfall amount during April-October. The contribution in the northern region reaches $\sim 50-90 \%$ and could highlight the importance of these events in the annual rainfall amount. Particularly, such high percentage in the northern region (i.e., above $12^{\circ} \mathrm{N}$ ) could be related to organized convective systems that contribute to $80 \%$ of the convective cloud cover and to $90 \%$ of the rainfall in the Sahel region [30].

3.2. Trends of Daily Extreme Rainfall. The linear trends of the gridded extreme rainfall events are also represented (Figure 3). The numbers of extreme rainfall days and the corresponding rainfall amounts are summed each year at each grid point. Then, the annual trend is plotted on the chronological series of the 18 years $\times 340$ grid points obtained from each variable (number of extreme rainfall days and the amount). Figure 3 shows that the southern region below $12^{\circ} \mathrm{N}$ experienced significant and negative trends of rainfall amount (Figure 3(a)). The highest decrease trends $(-40 \mathrm{~mm} /$ year and $-20 \mathrm{~mm} /$ year) are observed, respectively, 


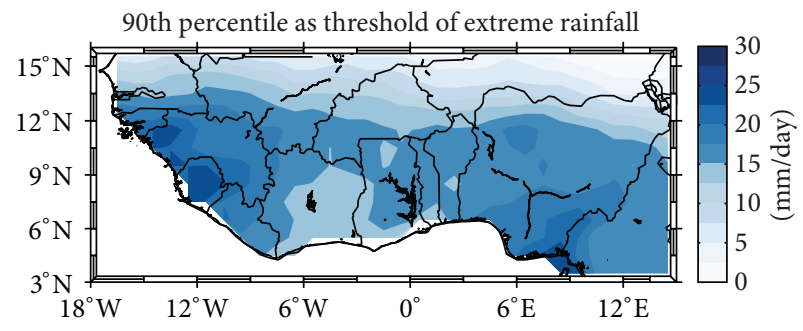

(a)

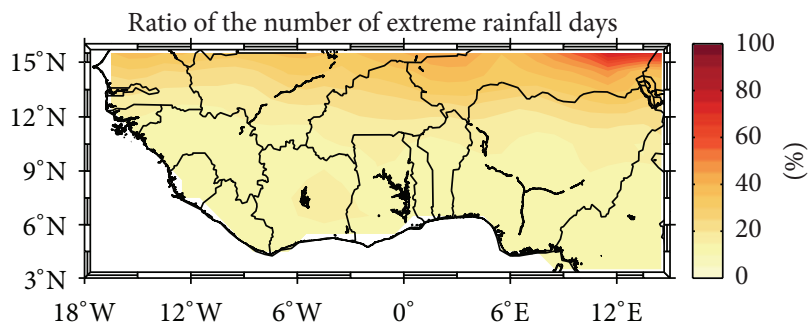

(b)

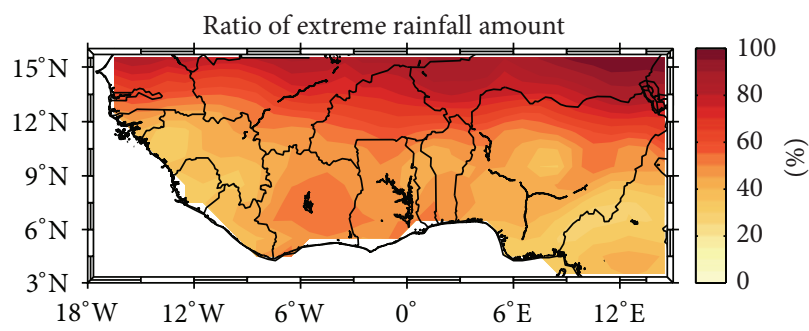

(c)

Figure 2: (a) Spatial distribution of the 90th-percentile values used as the thresholds above which each daily precipitation is defined as an extreme event. (b) Ratio pattern of the total number of extreme days. (c) Ratio pattern of the cumulated extreme events amount against the cumulated amount of the 3852 days.

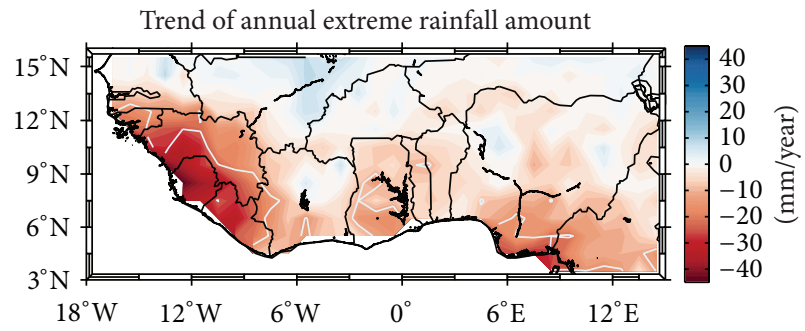

(a)

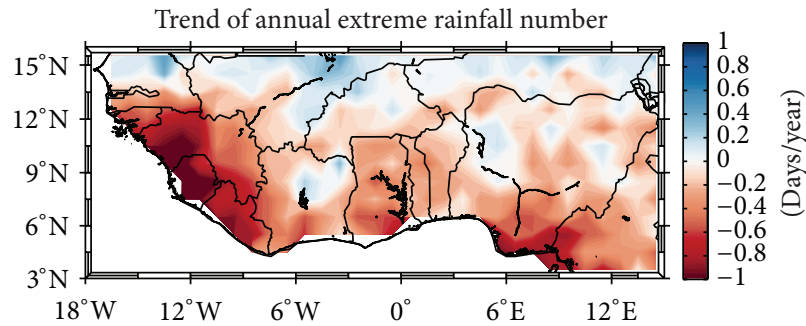

(b)

FIGURE 3: (a) Annual trend plotted on the chronological series of 18 years obtained from the cumulated rainfall amount and (b) the corresponding trend of the number of extreme days. Extreme rainfall events are obtained by applying the 90th-percentile threshold on the 3852 days. The white contours show the 95\%-level significant areas.

in the regions $6^{\circ} \mathrm{N}-12^{\circ} \mathrm{N} ; 17^{\circ} \mathrm{W}-10^{\circ} \mathrm{W}$ and $4^{\circ} \mathrm{N}-7^{\circ} \mathrm{N} ; 6^{\circ} \mathrm{E}-10^{\circ} \mathrm{E}$ where maximum thresholds were noticed (see Figure 2(c)). Nonsignificant trends are observed above $12^{\circ} \mathrm{N}$ where they are positive in the Sahel center between $7^{\circ} \mathrm{W}$ and $2^{\circ} \mathrm{W}$ and negative in the rest of this region. Negative and nonsignificant trends are obtained in the regions $6^{\circ} \mathrm{N}-12^{\circ} \mathrm{N} ; 17^{\circ} \mathrm{W}-10^{\circ} \mathrm{W}$ and $4^{\circ} \mathrm{N}-7^{\circ} \mathrm{N} ; 6^{\circ} \mathrm{E}-10^{\circ} \mathrm{E}$ for the number of days (Figure $3(\mathrm{~b})$ ). Positive and nonsignificant trends exhibited in the rest of the West Africa region and those of the two precedent areas show that the number of extreme days is mostly constant year to year and not linked to extreme rainfall variation.

The following panel (Figure 4) gives the monthly trends of the cumulated extreme rainfall amount during each selected month. All months present a decrease trend with the significant ones occurring from June to October in the regions $6^{\circ} \mathrm{N}-$ $12^{\circ} \mathrm{N} ; 17^{\circ} \mathrm{W}-10^{\circ} \mathrm{W}$ and $4^{\circ} \mathrm{N}-7^{\circ} \mathrm{N} ; 6^{\circ} \mathrm{E}-10^{\circ} \mathrm{E}$. The spatial pattern of the trends increasingly resembles the annual pattern from June onwards (see Figure 3(a)).
3.3. Variability Modes of Daily Extreme Rainfall. This subsection outlines the variability modes defined by the extreme rainfall amount. It is performed by using the empirical orthogonal functions (Eof) of the standardized anomalies calculated with the chronological series of the 18 years $\times 340$ grid points. Figure 5 illustrates the first four Eof spatial structures of the standardized anomalies of the extreme rainfall (Figures 5(a), 5(b), 5(c), and 5(d)) and their corresponding time series (Figures 5(e), 5(f), 5(g), and 5(h)). Only those Eof patterns that are physically significant $[31,32]$ are selected. These four patterns represent $89.6 \%$ of the explained variance. The white contours on Eof structures illustrate the significant areas at the $95 \%$ confidence level of Student's $t$-test while blue curves are the shapes of the time series.

The first mode (Figure 5(a)) represents $57.9 \%$ of the total variance. The structure shows a pattern of same sign of the extreme rainfall amount in West Africa. The significant area extends in the whole Sahel and in the south between $12^{\circ} \mathrm{W}$ 

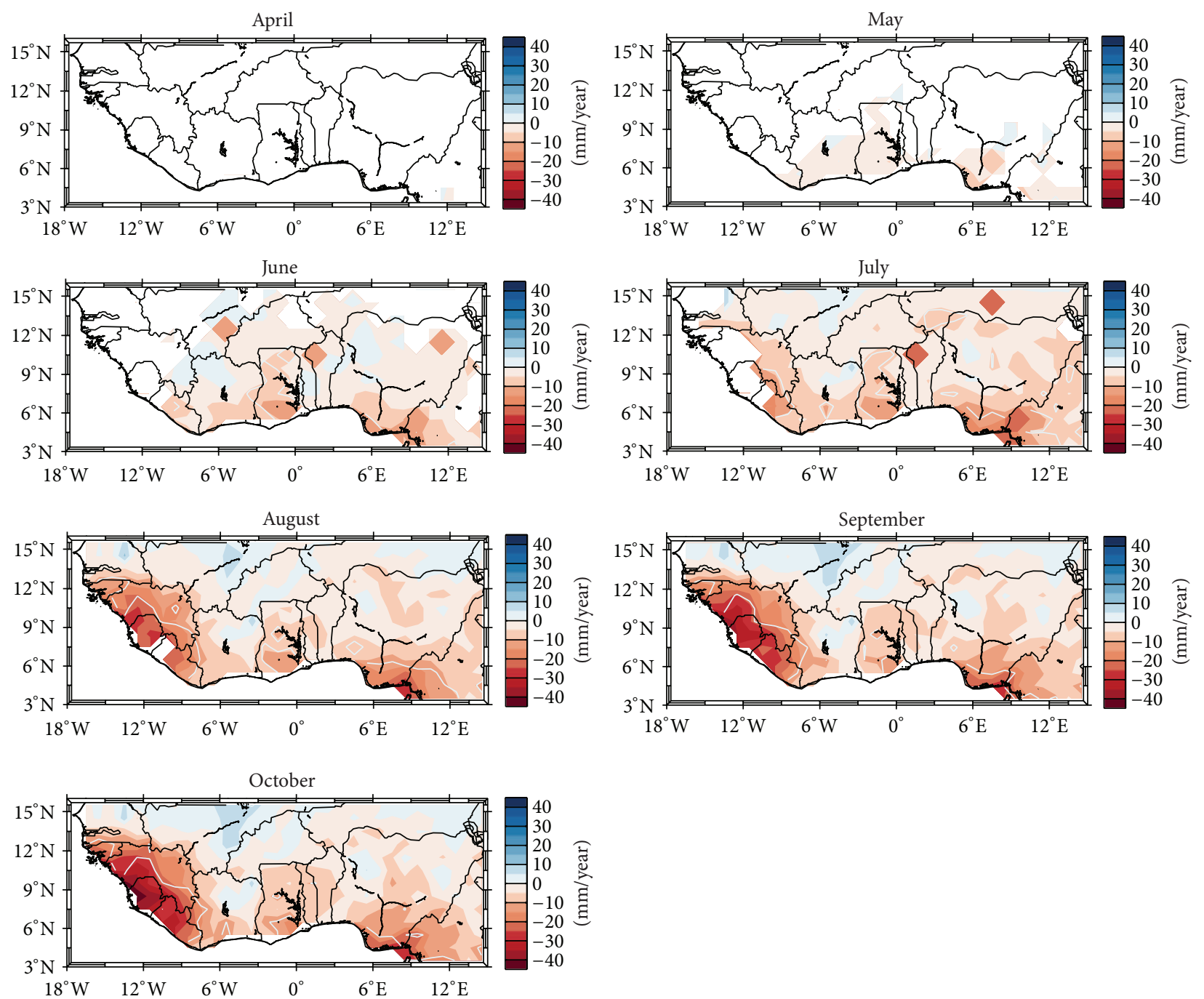

FIGURE 4: Monthly trend plotted on the chronological series of 18 years obtained from the cumulated rainfall amount. Extreme rainfall events are obtained by applying the 90th-percentile threshold on the 3852 days. The white contours show the $95 \%$-level significant areas.

and $6^{\circ} \mathrm{W}$. The combination analysis of the structure and the time series (Figure 5(e)) indicates a uniform decrease trend across West Africa even if it is not significant (not shown). When looking at the time series (Figure 5(e)), the panel indicates a low-frequency fluctuation in 1997-2007 and a year-to-year fluctuation of extreme rainfall since 2008. That could mean more frequent extreme events during the last decade than before 2008. The highest extreme rainfall amounts are noted in 1998, 1999, and 2003, which are wet years since they are in phase with the first Eof structure. Such extreme events affected one million people in 1998 and 1999 in height and eleven West African countries, respectively [33]. These wet years could have experienced larger number of convective systems in opposition to dry years which could have primary result of fewer ones, mainly in July and August $[34,35]$. The highest extreme rainfall deficits are observed in 2009 and 2011 in the entire Sahel region. However, some towns experienced extreme rainfall exceedance as, for instance, in Niamey (Niger) in 2011 and rainfall amount up to $300 \mathrm{~mm}$ that occurred during two days (August 31 to September 01, 2009) in Ouagadougou (Burkina Faso) and caused serious social and economic damage (http://reliefweb.int/disaster/fl-2009-000172-bfa).

The second mode (Figure 5(b)) which represents 16.3\% of the total variance illustrates a contrast between Sahelian zone and the southern zone of West Africa. A decrease of extreme rainfall amount is observed above $12^{\circ} \mathrm{N}$ with a slight incursion into the north of the coastal countries (Côte d'Ivoire, Ghana, Togo, Benin, and Nigeria) whereas increase in extreme rainfall amount is noticed below $12^{\circ} \mathrm{N}$. This last area highlights a large significant zone located in the eastern part of West Africa that includes the south of Nigeria. The associated time series (Figure 5(f)) exhibits extreme rainfall exceedance during 1997-2007 with the highest one being in 2006, while extreme rainfall deficit is observed during the 2008-2014 period. Okorie et al. [36] documented the extreme event of 2006. They observed a very high precipitation and an increasing surface air 


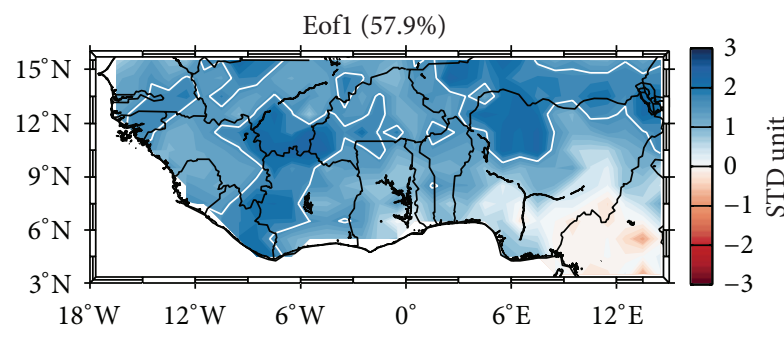

(a)

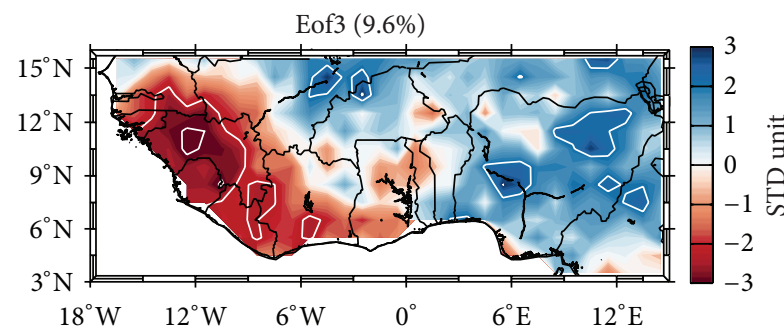

(c)

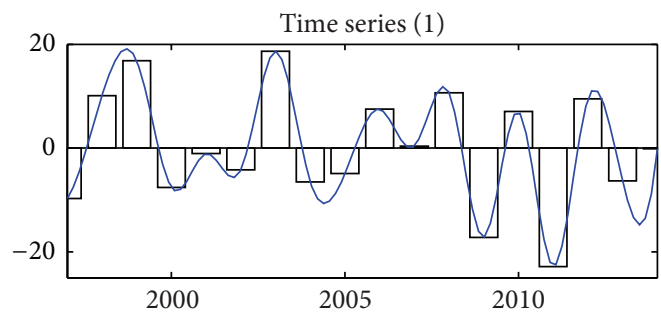

(e)

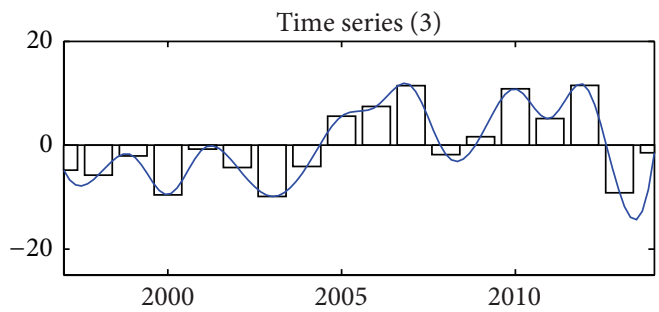

(g)

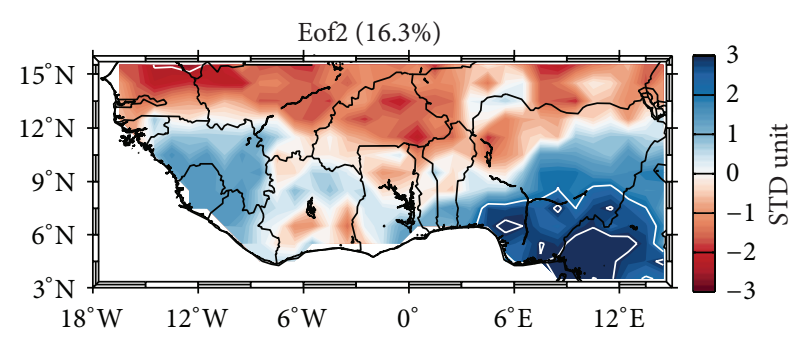

(b)

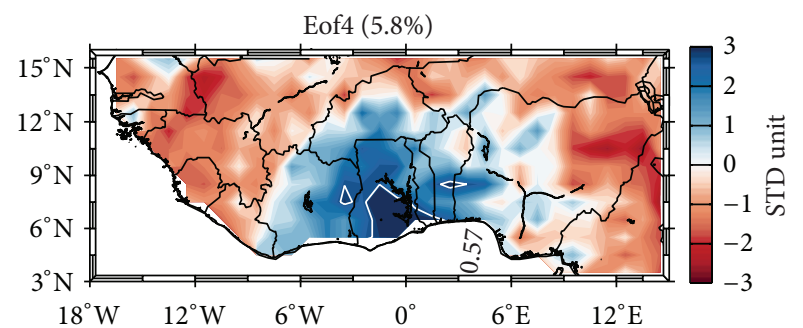

(d)

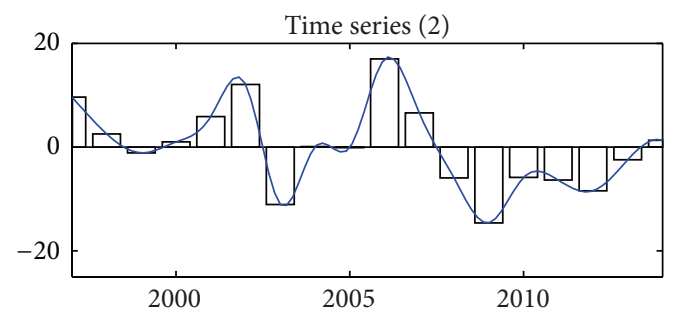

(f)

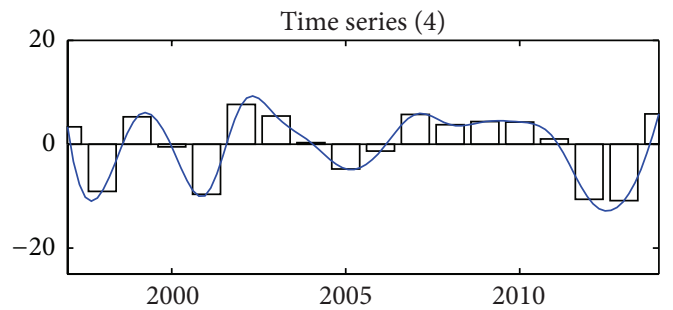

(h)

Figure 5: The first four Eof spatial patterns of the extreme rainfall standardized anomalies calculated on the chronological series of the 18 annual values $\times 340$ grid points $((\mathrm{a}),(\mathrm{b}),(\mathrm{c})$, and $(\mathrm{d}))$ and their corresponding time series $((\mathrm{e}),(\mathrm{f}),(\mathrm{g})$, and $(\mathrm{h}))$. The white contours show the 95\%-level significant areas while blue curves are the shapes of the time series.

temperature in Nigeria during this same year. Both increases implied a rise of malaria cases due to high rates of mosquito breed.

The third mode (Figure 5(c)) explains $9.6 \%$ of the total variance. The structure presents an east-west contrast characterized by a significant reduction of the extreme rainfall westward inside $0^{\circ}-18^{\circ} \mathrm{W} ; 3^{\circ} \mathrm{N}-12^{\circ} \mathrm{N}$ (including Guinea, Sierra Leone, Liberia, and Guinea-Bissau) and a nonsignificant increase both in the Sahel and in the eastern zone of the studied region. The first period (1997-2004) of the associated time series (Figure 5(g)) shows negative values of the scores while those of the second period (2005-2012) are positive. However, when looking at the associated Eof structure which is also significantly negative at the western part of West Africa, one can conclude that these periods indicate extreme rainfall exceedance and a deficit during the 1997-2004 and
2005-2012 periods, respectively. For example, McSweeney et al. [37] noted that the height of rainfall in Liberia was very low in 2005 and 2006. These observations could be checked when the annual anomalies of the extreme rainfall are plotted (not shown).

The fourth mode (Figure 5(d)) explains 5.8\% of the total variance. It represents a significant increase of the extreme rainfall in the coastal countries (Ghana and Togo) and a nonsignificant deficit over the rest of West Africa. This coincides with that highlighted by Ali et al. [38]. The associated time series (Figure 5(h)) shows five years of rainfall exceedance in 2007-2011 followed by two years of extreme rainfall deficit during 2012-2013. For example, the torrential rain on Thursday June 05, 2014, in Accra (Ghana) caused flooding that blocked roads and transport (http://floodlist.com/africa/ accra-ghana-floods-june-2014). 


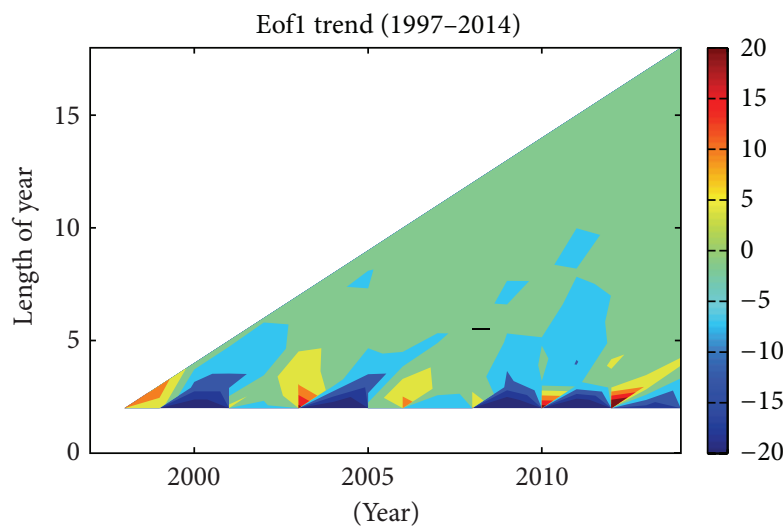

(a)

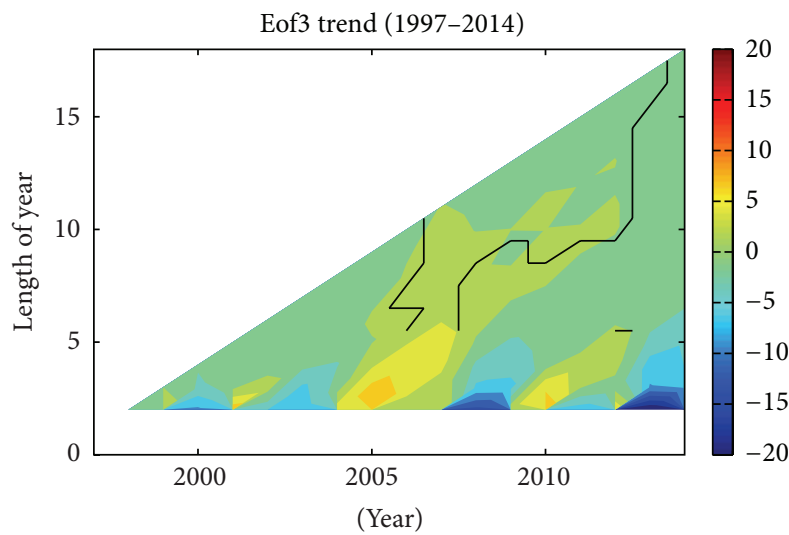

(c)

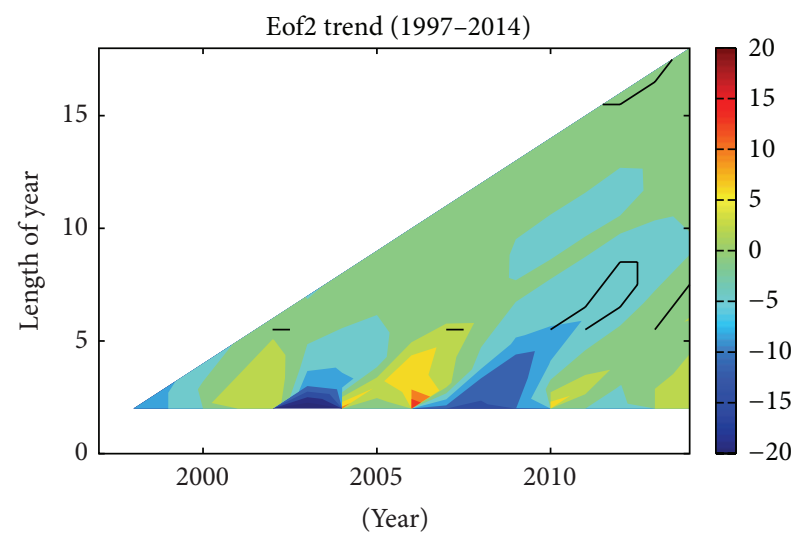

(b)

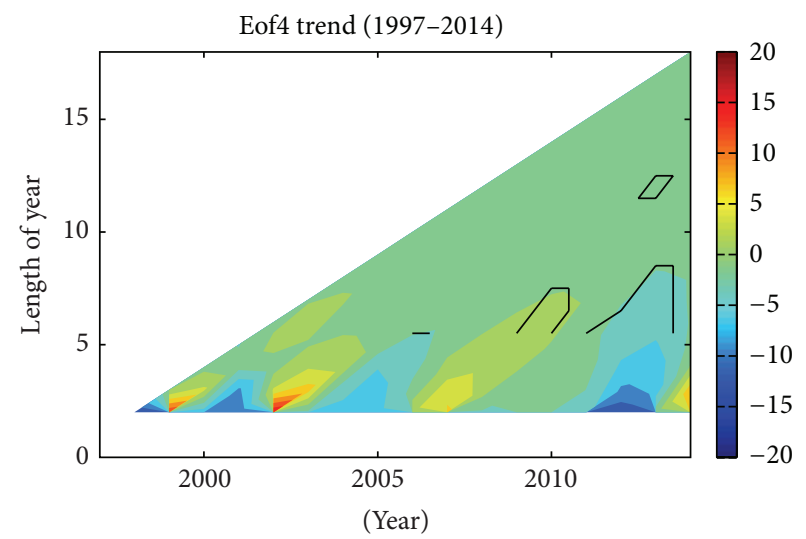

(d)

Figure 6: Trends of the four Eof time series from 1997 to 2014 as a function of length of time segment and ending year of calculation; the black contours provide the confidence ranking Student's $t$-test.

A complementary analysis of the interannual study of the Eof time series is now provided by using a statistical diagnostic based on the linear regression [39]. This method is used to objectively detect one or more tendency breaks in the Eof scores and when they occur. Figure 6 displays every possible trend for each Eof and corresponding confidence Student's $t$-test during each time segment from a 2-year to an 18-year period (the total length of the available Eof time series). If the first Eof time series is considered (see Figure 6(a)), the value plotted at point $x=2011, y=6$ corresponds to the 6-year trend ( -5 standardized anomalies per year) computed during the time segment 2005-2011. One can note that trends with longer segments are quite weak compared to those corresponding to shorter segments.

In the case of Eof1 (Figure 6(a)), no long-term trend break exists for this structure even if, for time segments greater than 4 years, the trend remains negative. This is in agreement with Figure 6(a) for which annual negative trend is located above $12^{\circ} \mathrm{N}$. The graph for Eof 2 (Figure 6(b)) exhibits a negative significant trend at the $95 \%$ confidence level in 2010-2012 for a time segment of 6-8 years and in 20112013 for a time segment of 15-17 years. Such remark is in agreement with annual negative trend (see Figure 3(a)) for the eastern region including Nigeria. Significant positive trends are found for time segments between 6 and 12 years, that is, in 2006-2012 for Eof3 (Figure 6(c)). When considering time segments greater than 12 years, the significant negative trends are in agreement with the annual trend. The last analysis is about Eof4 (Figure 6(d)) for which time segments ranged between 6 and 8 years showing significant positive and negative trends in 2009-2011 and 2011-2013, respectively. In conclusion, a 6-year trend seems to characterize the last three Eof (Eof2, Eof3, and Eof4) time series even if they present different trend patterns. Such 6-year trend is in agreement with the 6-year fluctuation common throughout much of Africa and could be associated with the peak frequency of the southern oscillation [40].

3.4. Atmospheric Conditions during the Selected Events and Large Scale of Ocean Surface. The West African monsoon impact on the four variability modes is firstly studied by applying the methodology of Diawara et al. [19]. It stipulates that, around $6.13^{\circ} \mathrm{N} ; 5.02^{\circ} \mathrm{W}$, the monthly atmospheric level reached by the monsoon flux coming from the ocean (south to north direction) is characterized when the NCEP-NCAR meridional wind direction [28] changes from positive to negative value. The maximum level of the climatology Diawara et al. [19] plotted did not exceed $700 \mathrm{hPa}$ in agreement with many studies on easterly waves over West Africa [41, 42]. 


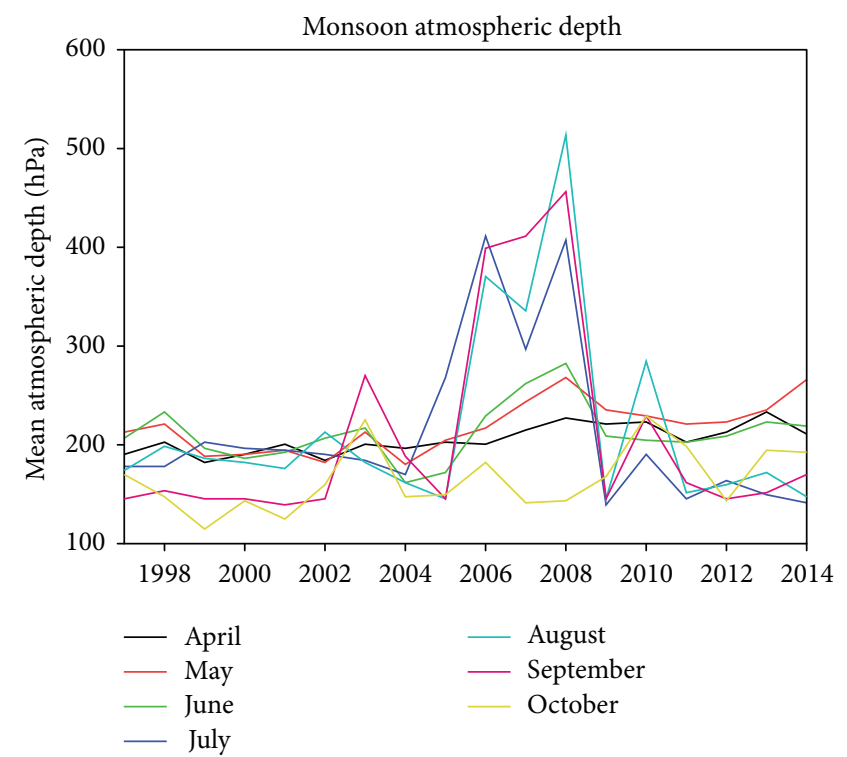

(a)

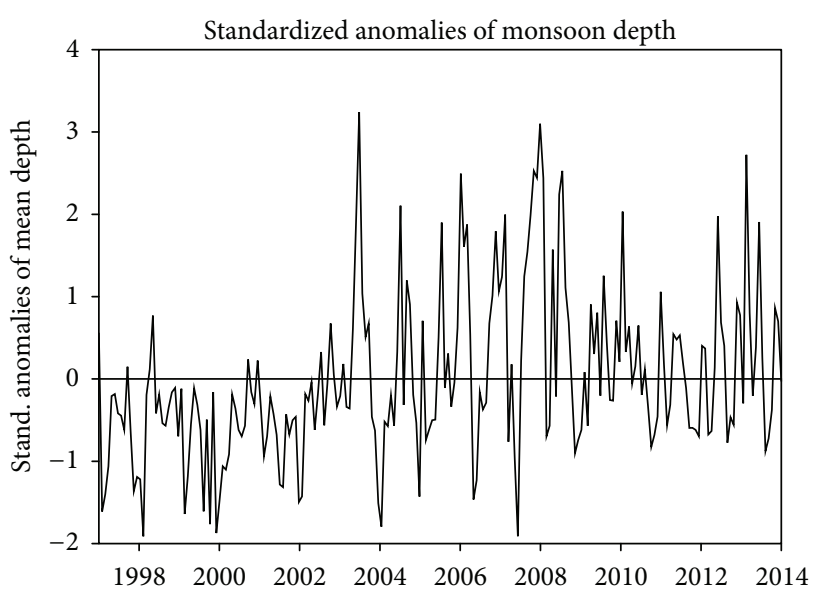

(b)

Figure 7: (a) Monthly evolution of the mean atmospheric level reached by the monsoon flow during April to October in 1997-2014. (b) Standardized anomalies of the atmospheric depth of the monsoon calculated from January to December.

Figure 8(a) shows the monthly evolution of the mean atmospheric depth calculated as the difference between $1000 \mathrm{hPa}$ and the monthly level reached by the flow. It reveals an increase of the mean atmospheric depth from 2003 up to 2014 during all months. This period is consistent with the increase rainfall in 1997-2007 noted in the second Eof time series. Particularly, strong perturbations are observed in the monsoon depth in July-September during 2005-2008. The monsoon flux reached higher depth $(\sim 500 \mathrm{hPa})$ in $2005-$ 2008. The plot of the standardized anomalies of the mean depth (Figure 7(b)) corroborates the observation based on the monthly mean. Actually, the trend is positive from 1998 to 2003, and then it maintains mostly large, positive values from 2003 to 2014. Such increase and perturbations in the mean atmospheric depth could allow the monsoon flux penetrating far into the land and influence the rise of the extreme rainfall amount. A 6-year trend in the monsoon depth can be observed when using the statistical diagnostic based on the linear regression [39] (not shown). Such trends could be associated with the 6-year trend noted in the Eof time series (see Figure 6) and then with the peak frequency of the southern oscillation [40].

The impact of the large scale of the oceanic surface and atmospheric conditions on the four variability modes defined by the Eof of the standardized extreme rainfall anomalies is now undertaken. It is studied by performing composite patterns of SST, latent heat flux, vertical wind, and horizontal moisture flux. This last parameter is calculated as the product between NCEP horizontal wind and specific humidity data at $700 \mathrm{hPa}$.

Figure 8 shows the composite patterns of SST performed as the difference between years of extreme rainfall exceedance and those of extreme rainfall deficit from the Eof time series. The corresponding composite moisture flux at $700 \mathrm{hPa}$ is superimposed on each pattern. The SST composite structure (Figure 8(a)) from Eof1 (hereafter SST1) shows positive and significant values along the equatorial band and off Angola. This oceanic region has been previously defined as the Atlantic cold tongue [43]. It suggests that an anomalous warming, in the equatorial oceanic region from $40^{\circ} \mathrm{W}$ to $15^{\circ} \mathrm{E}$ and off Angola, is associated with an intensification of the extreme rainfall events mostly in the Sahel. The opposite SST anomalies pattern is associated with less intense extreme rainfall. Such relationship for the Sahel region is obvious since it has been shown in the previous sections that extreme rainfall contributes to $50-90 \%$ of the total rainfall amount in this area. The significant SST1 warming inside the $40^{\circ} \mathrm{W}-$ $10^{\circ} \mathrm{W}$ band in the Atlantic cold tongue is associated with an anomalous deceleration of the wind at $700 \mathrm{hPa}$ level between $0^{\circ}$ and $10^{\circ} \mathrm{N}$, with an intensification of the wind off Angola, and with a reinforcement of the anticyclone of Saint-Helena. They allow the penetration of the moisture flux into the continent where it accelerates northward toward the Sahel. Another westward moisture flux structure (in $12^{\circ} \mathrm{N}-22^{\circ} \mathrm{N}$; $\left.20^{\circ} \mathrm{W}-15^{\circ} \mathrm{E}\right)$ is linked to that noticed in the $40^{\circ} \mathrm{W}-10^{\circ} \mathrm{W}$; $0^{\circ}-10^{\circ} \mathrm{N}$ domain by a cyclonic circulation in the vicinity of the Joss Plate, a frequent zone of MCSs initiation. This last structure at $12^{\circ} \mathrm{N}-22^{\circ} \mathrm{N} ; 20^{\circ} \mathrm{W}-15^{\circ} \mathrm{E}$ could correspond to an intensification of the African Easterly Jet [41] during intensification of the extreme rainfall in the Sahel region.

The SST2 composite structure (Figure 8(b)) indicates negative and significant structures anomalies in the vicinity of South America at $10^{\circ} \mathrm{N}$ and close to the coast of MauritaniaSenegal at $12^{\circ} \mathrm{N}$. The slanting axis which could join these two negative structures coincides with the latitudinal band of the intertropical convergence zone (ITCZ). It means that the cooling of this oceanic zone is associated with an intensification of the extreme rainfall events in the eastern 


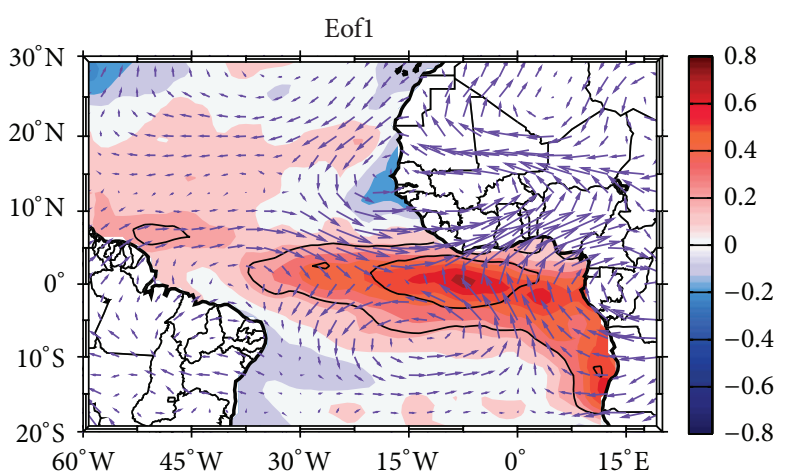

(a)

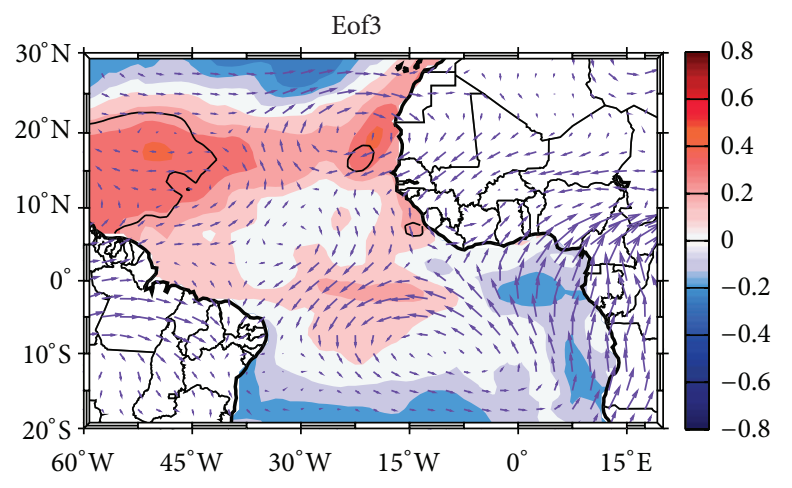

(c)

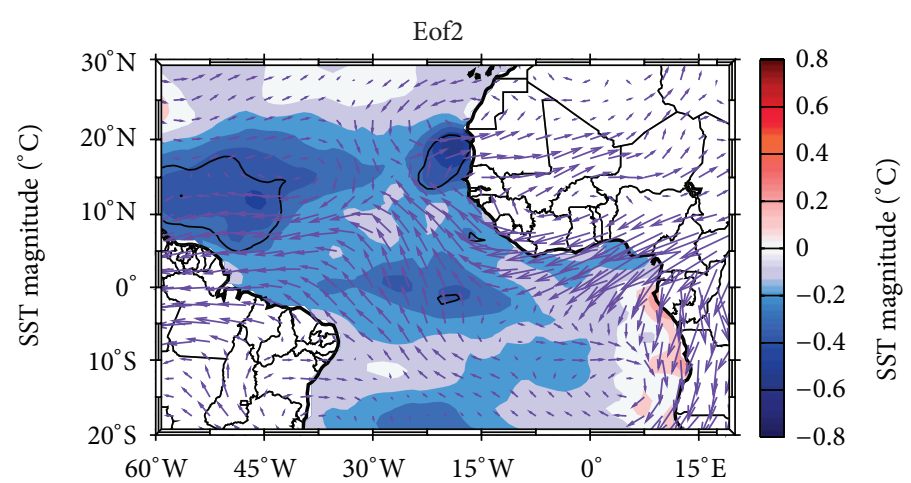

(b)

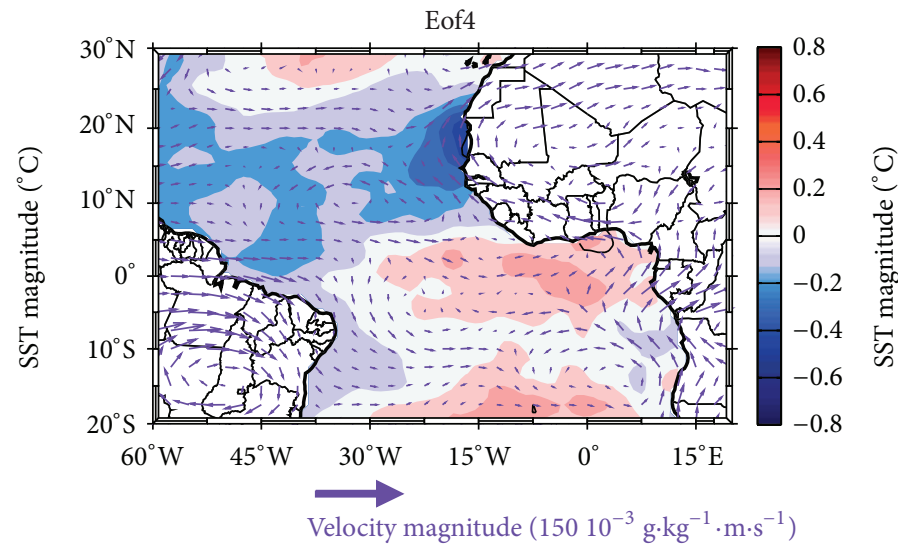

(d)

FIGURE 8: Composite patterns of SST (shaded) and moisture flux at $700 \mathrm{hPa}$ (blue vectors, $10^{-3} \mathrm{~g} \mathrm{~kg}^{-1} \mathrm{~m} \mathrm{~s}^{-1}$ ) performed as the difference between years of extreme rainfall exceedance and those of extreme rainfall deficit from the time series of the extreme rainfall amount of (a) Eof1, (b) Eof2, (c) Eof3, and (d) Eof4. Black contours on the tropical Atlantic provide the 95\% confidence Student's $t$-test.

part of West Africa including the south of Nigeria. The opposite SST anomalies pattern is associated with less intense extreme rainfall. The area of cooling SST coincides with eastward incursion of moisture flux around $20^{\circ} \mathrm{N}$ in West Africa at $700 \mathrm{hPa}$. The association between cooling SST and eastward moisture flux could signify that no humidity is transported from the ocean to the area delineated by the second Eof. However, this panel shows that the increase of the extreme rainfall events in this east zone is influenced by the eastern moisture flux from $20^{\circ} \mathrm{E}$ that covers the Joss Plate region.

The SST3 composite structure (Figure $8(\mathrm{c})$ ) indicates a significant warming inside $5^{\circ} \mathrm{N}-20^{\circ} \mathrm{N} ; 60^{\circ} \mathrm{W}-35^{\circ} \mathrm{W}$ and at $15^{\circ} \mathrm{N} ; 20^{\circ} \mathrm{W}-15^{\circ} \mathrm{W}$ that envelops the area of the latitudinal evolution of the ITCZ. It means that warming in these oceanic regions is associated with an intensification of extreme rainfall events. This can be observed on moisture flux composite structure that penetrates around $20^{\circ} \mathrm{N}-25^{\circ} \mathrm{N}$ in the third variability mode shown by the Eof analysis. The increase of the extreme rainfall amount is also associated with the reinforcement of the two anticyclones of Azores and SaintHelena which come closer at $20^{\circ} \mathrm{N}$ and $10^{\circ} \mathrm{S}$, respectively, and with the intensification of the moisture flux from the east of West Africa at $20^{\circ} \mathrm{E} ; 15^{\circ} \mathrm{N}$.
The last SST4 composite structure (Figure 8(d)) shows a small significant warming close to the northern coast of the Gulf of Guinea. The whole part of the Atlantic Ocean remains nonsignificant. The plot of the moisture flux vectors at $700 \mathrm{hPa}$ shows a deceleration of trades between $0^{\circ}$ and $5^{\circ} \mathrm{N}$ illustrating a weak penetration of humidity on the Eof 4 zone.

The moisture exchange process that develops at the oceanic surface is analysed by using the latent heat (LH) flux composite in the same manner as in Figure 8. Positive LH composite differences from the first Eof (Figure 9(a)), related to energy loss by evaporation from the ocean surface to the atmosphere, are noted practically in the whole southern tropical Atlantic basin. It could mean that more evaporation from ocean occurred during the extreme rainfall exceedance. The oceanic region of positive difference $\mathrm{LH}$ is coincident with the oceanic region where positive SST composite was observed for the first Eof. The second LH composite pattern from Eof2 (Figure 9(b)) shows positive differences close to the meridional coast of Africa in the southern basin of the tropical Atlantic. This structure extends westward and coincides with coastal positive composite of SST and to the westward direction of the $700 \mathrm{hPa}$ moisture flux (see Figure $8(\mathrm{~b})$ ). It could indicate that the evaporation over the ocean does not penetrate into the zone defined by the 


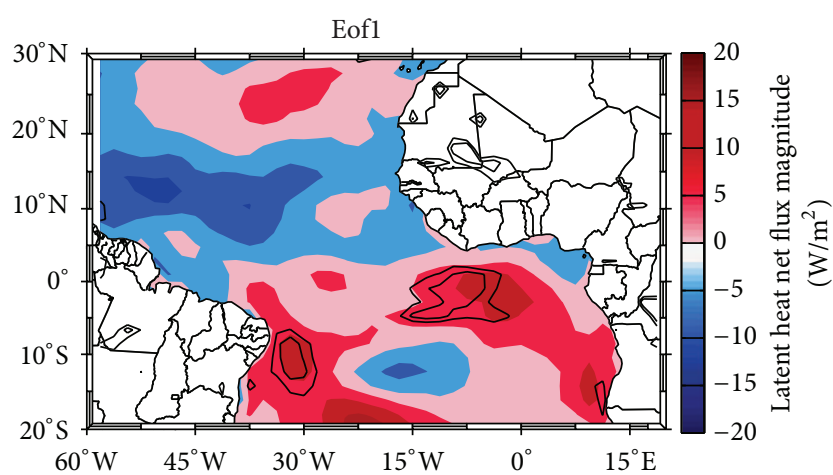

(a)

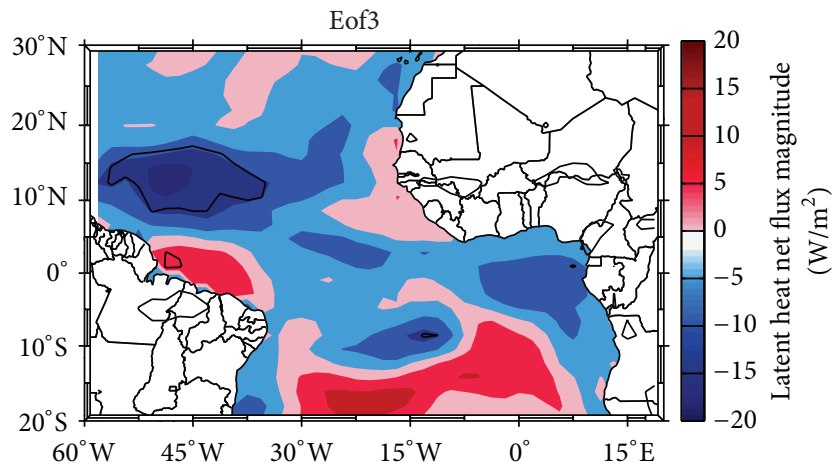

(c)

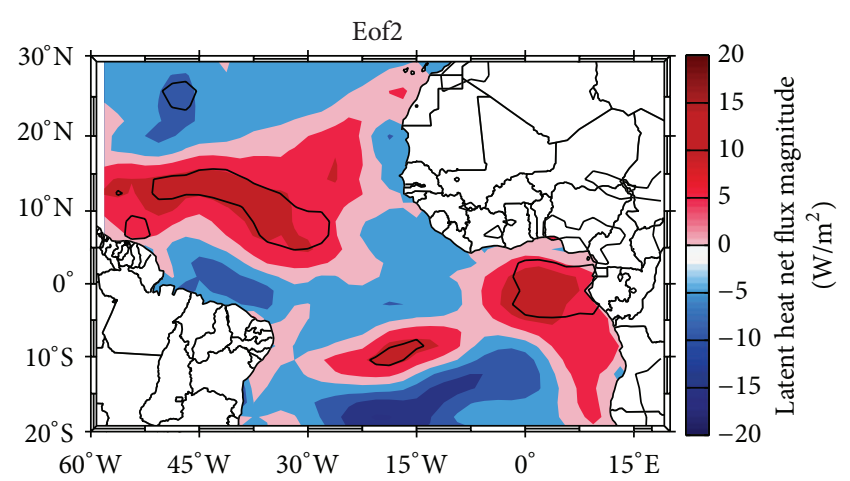

(b)

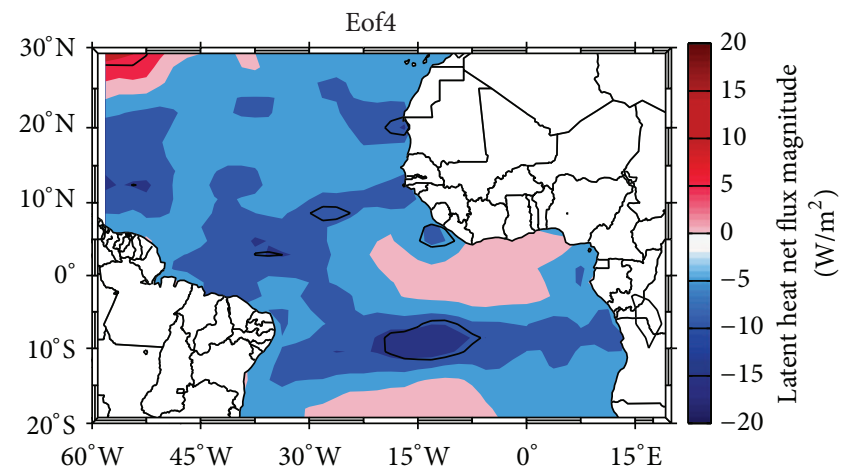

(d)

FIGURE 9: Composite patterns of latent heat $(\mathrm{LH})$ flux $\left(\mathrm{W} \mathrm{m}^{-2}\right)$ performed as the difference between years of extreme rainfall exceedance and those of extreme rainfall deficit from the time series of the extreme rainfall amount of (a) Eof1, (b) Eof2, (c) Eof3, and (d) Eof4. Black contours on the tropical Atlantic provide the $95 \%$ confidence Student's $t$-test.

Eof mode. That could imply a decrease in extreme rainfall amount. In the northern basin of the tropical Atlantic, a large structure of positive $\mathrm{LH}$ composite within $60^{\circ} \mathrm{W}-20^{\circ} \mathrm{W}$ is concomitant with a negative $\mathrm{LH}$ one close to the permanent upwelling of the Mauritania-Senegalese coast. This last zone helps in stabilizing the air mass and does not allow the transportation of the moisture flux over the zone defined by the Eof mode. The third composite pattern (Figure 9(c)) presents no-homogeny structure of LH difference as those of the previous two Eof modes. Both negative and positive cells are observed in the two ocean basins. Interesting is the positive $\mathrm{LH}$ difference within $25^{\circ} \mathrm{W}-20^{\circ} \mathrm{W}$ close to the western coast of Africa. This positive LH structure is in agreement with the significant warming of SST and with the eastward penetration of the $700 \mathrm{hPa}$ moisture flux. Finally, the fourth LH composite pattern shows negative values in the tropical Atlantic, excepted within $20^{\circ} \mathrm{W}-5^{\circ} \mathrm{E}$ at the northern coast of the Gulf of Guinea where they are positive. This last region coincides with the warming SST region (see Figure $8(\mathrm{~d})$ ).

Figure 10 depicts the altitude-longitude composite diagram of the vertical velocity $\left(10^{-3} \mathrm{~Pa} \mathrm{~s}^{-1}\right)$ averaged over $5^{\circ} \mathrm{S}-10^{\circ} \mathrm{N}$ along $60^{\circ} \mathrm{W}-15^{\circ} \mathrm{E}$ from $200 \mathrm{hPa}$ to $1000 \mathrm{hPa}$. This figure illustrates only the composite patterns for extreme rainfall exceedance (left) and extreme rainfall deficit (right) from each Eof mode. No differences between these two patterns are undertaken like for the previous figures (see Figures 8 and 9). Negative values indicate an upward motion of air, which can carry moisture from the ocean to the troposphere, while positive values indicate a subsidence of air.

The vertical motion composite from Eof1 (Figure 10(a)) is upward within the whole troposphere between $40^{\circ} \mathrm{W}$ and $25^{\circ} \mathrm{W}$ for extreme rainfall exceedance, whereas air subsidence occurs just above the sea surface for extreme rainfall deficit. Another difference between these two patterns is observed within $850-950 \mathrm{hPa}$ at $20^{\circ} \mathrm{W}$ where upward motion (resp., subsidence) can be noticed for extreme rainfall exceedance (resp., extreme rainfall deficit). The two panels also show upward motion on the continent. Thus, the moisture flux from the excess of evaporation in the southern tropical Atlantic basin (see Figure 9(a)) could be transported upward in the atmospheric low levels and reach the continent through the eastward propagating moisture flux. That is in agreement with Li et al. [44] who noticed that an enhancing convergence movement in the lower troposphere involves the development of the monsoon circulation. Then, strengthening eastern wind carried out moisture from the Atlantic and the Gulf of Guinea to the West Africa continent. The combination of moisture from ocean and that from the upward motion over the continent could imply the increase of the extreme rainfall amount. 

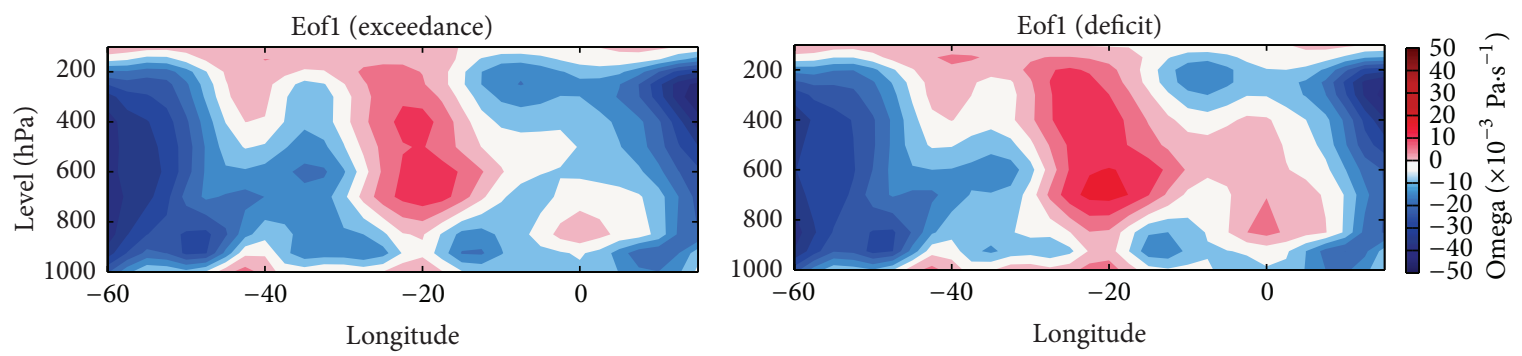

(a)
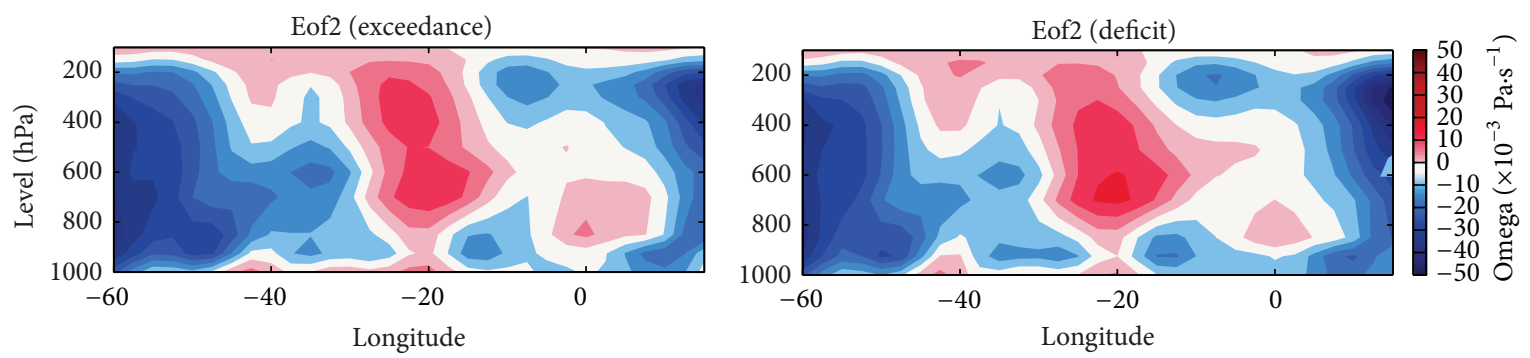

(b)
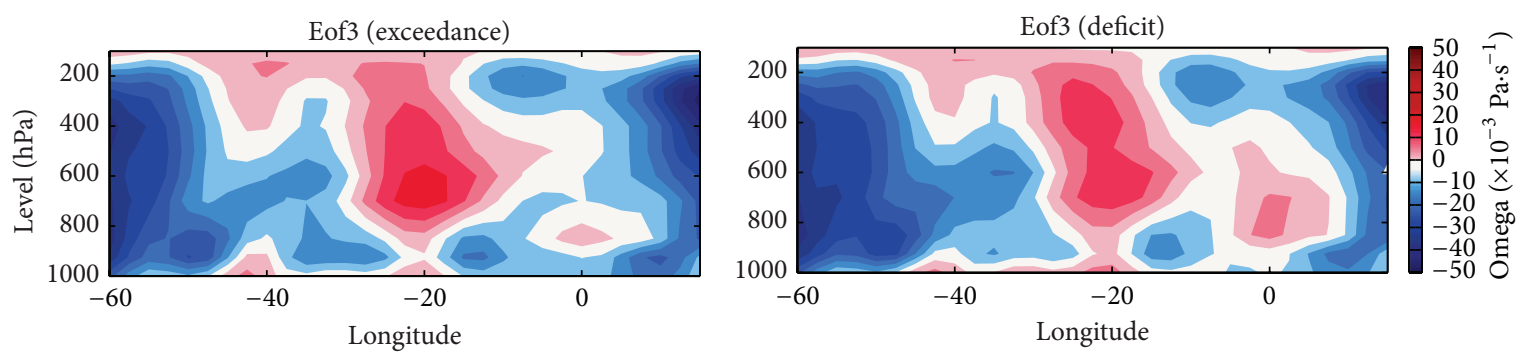

(c)
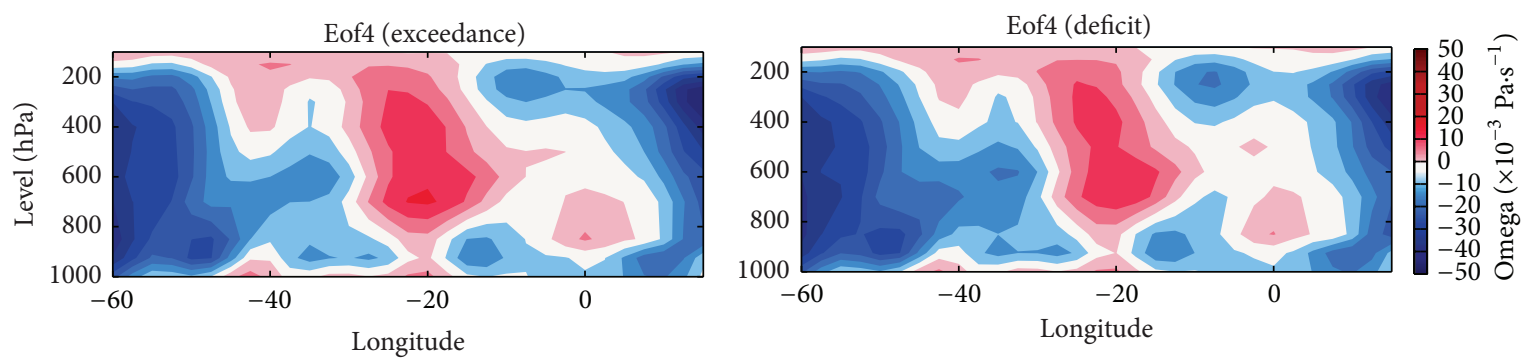

(d)

Figure 10: Altitude-longitude composite patterns of vertical velocity $\left(10^{-3} \mathrm{~Pa} \mathrm{~s}^{-1}\right)$ averaged over $5^{\circ} \mathrm{S}-10^{\circ} \mathrm{N}$ for the composite patterns for extreme rainfall exceedance (left) and extreme rainfall deficit (right) from the time series of the extreme rainfall amount of each Eof mode.

The vertical motion composite from Eof2 (Figure 10(b)) presents air subsidence above the sea surface between $50^{\circ} \mathrm{W}$ and $20^{\circ} \mathrm{W}$ for both patterns. Moreover, the vertical subsidence at $20^{\circ} \mathrm{W}$ acts as a barrier that does not allow the air from the ocean to penetrate into the continent. When looking at the two panels, upward motion can be noticed in the atmospheric low levels. Such remarks could be related to the previous analyses for the second Eof mode. Thus, the cooling of SST in the whole tropical Atlantic implies less evaporation over the ocean. This does not allow the moisture flux to be transported eastward from the ocean to the continent (see Figure 8(b)). In conclusion, the rise of rainfall extreme amount could be influenced by the convection over the continent. This moisture is transported westward from $20^{\circ} \mathrm{E}$ that covers the Joss Plate region.

The vertical motion composite from Eof3 (Figure 10(c)) is similar to that of Eofl, but with a weak depth of upward motion between $900 \mathrm{hPa}$ and $950 \mathrm{hPa}$ at $20^{\circ} \mathrm{W}$. The upward motion of moisture over the ocean could be due to the excess of evaporation from the warming ocean inside $5^{\circ} \mathrm{N}-20^{\circ} \mathrm{N}$; $60^{\circ} \mathrm{W}-35^{\circ} \mathrm{W}$ and at $15^{\circ} \mathrm{N} ; 20^{\circ} \mathrm{W}-15^{\circ} \mathrm{W}$. The reinforcement of the two anticyclones and particularly that of the Azores allows the moisture to be transported eastward on the continent (see Figure 8(c)). This remark is also in agreement with $\mathrm{Li}$ 
et al. [44] as previously noted for Eofl. Such ocean moisture and that produced in the continent contribute to the extreme rainfall amount increase.

The vertical motion composite from Eof4 (Figure 10(d)) is also analysed. The patterns are similar to those of Eof2. Such atmospheric characteristics are in agreement with the small warming close to the northern coast of the Gulf of Guinea that led to evaporation in this region. This moisture does not penetrate far into the continent but remains localized in some coastal countries of West Africa. This contributes to the increase of the extreme rainfall amount in these areas.

\section{Conclusion}

This work aims to study trends and variability of daily extreme rainfall in West Africa. It also analyses the relationships between these rainy events and the large-scale ocean surface and atmospheric conditions in the tropical Atlantic. A set of gridded daily precipitation data from the Global Precipitation Climatology Project (GPCP), sea surface temperature of Reynolds, vertical wind, latent heat flux, and moisture flux calculated from NCEP-NCAR horizontal wind and specific humidity from April to October in 1997-2014 are used for the different estimates. This period includes the rainfall seasons over West Africa $\left(18^{\circ} \mathrm{W}-15^{\circ} \mathrm{E} ; 3^{\circ} \mathrm{N}-16^{\circ} \mathrm{N}\right)$.

A threshold as the 90th percentile at each grid point from the chronological series of 3852 values (i.e., 214 values per year $\times 18$ years at each grid) is firstly carried out. Then extreme daily rainfall is identified as precipitation exceeding the gridded 90 th percentile. These thresholds decrease from the southern to the Sahelian regions. They define areas of high values, which are known to be the rainiest areas and to have the longest rainy season in West Africa. The contribution of the extreme rainfall amount during April-October reaches $30-50 \%$ in the southern region. This contribution ( $50-90 \%)$ in the northern region of West Africa could highlight the importance of these events in the annual rainfall. Statistical analyses from the yearly cumulated extreme rainfall amount show significant and negative trends in the southern region of West Africa. The spatial pattern of the monthly trends in JulyAugust is similar to the annual one. The nonsignificant trends of the number of days could mean that it is mostly constant and not linked to the extreme rainfall amount variation.

The statistical analysis is achieved by performing empirical orthogonal functions (Eof) of the standardized anomalies calculated on the gridded chronological series. Four variability modes have been defined by the extreme rainfall amount. Eof1 structure shows a decrease and significant extreme rainfall amount that extends to the Sahel and the south of West Africa between $12^{\circ} \mathrm{W}$ and $6^{\circ} \mathrm{W}$. The north-south contrast in Eof2 highlights a significant zone located in the eastern part of West Africa that includes the south of Nigeria. The third Eof3 structure indicates an east-west contrast characterized by a significant reduction of the extreme rainfall westward inside $0^{\circ}-18^{\circ} \mathrm{W} ; 3^{\circ} \mathrm{N}-12^{\circ} \mathrm{N}$, whereas the fourth Eof 4 structure represents a significant increase of the extreme rainfall in the coastal countries of Ghana and Togo. A complementary analysis of the Eof time series based on the linear regression does not show long-term trend break for the four Eof.
However the last three Eof are characterized by a 6-year trend which could be associated with the peak frequency of the southern oscillation.

The West African monsoon impact on the four variability modes shows strong perturbations of the mean atmospheric depth. A 6-year trend on this depth is in agreement with that of Eof time series. These remarks explain that the monsoon flow could penetrate far into the land and influence the rise of the extreme rainfall amount. Finally, four different composite structures of SST and moisture flux at $700 \mathrm{hPa}$, latent heat flux, and vertical motion illustrate the impact of the large-scale ocean surface and atmospheric conditions on the variability modes. For Eofl, an anomalous warming in the Atlantic cold tongue, inducing excess of evaporation, is associated with an intensification of the extreme rainfall events. It is related to an anomalous deceleration of the trades at $700 \mathrm{hPa}$ between $0^{\circ}$ and $10^{\circ} \mathrm{N}$, to an intensification of the wind off Angola, and to a reinforcement of the anticyclone of Saint-Helena. An additional westward moisture flux structure at $12^{\circ} \mathrm{N}-22^{\circ} \mathrm{N}$ from $20^{\circ} \mathrm{W}$ to $15^{\circ} \mathrm{E}$ originates from a cyclonic circulation in the vicinity of the Joss Plate, a frequent zone of MCSs initiation. The Eof 2 mode may be influenced by the moisture flux from $20^{\circ} \mathrm{E}$ that covers the Joss Plate region. In fact, the subsidence above the ocean surface does not allow the moisture flux to be transported eastward from the ocean to the continent. For Eof3, significant warming of SST inside $5^{\circ} \mathrm{N}-20^{\circ} \mathrm{N} ; 60^{\circ} \mathrm{W}-35^{\circ} \mathrm{W}$ and at $15^{\circ} \mathrm{N} ; 20^{\circ} \mathrm{W}-15^{\circ} \mathrm{W}$ induces an excess of evaporation. It is associated with an intensification of the extreme rainfall events. It also coincides with the moisture flux penetrating around $20^{\circ} \mathrm{N}-25^{\circ} \mathrm{N}$, the reinforcement of the two anticyclones of Azores and SaintHelena, and the intensification of the moisture flux from the east of West Africa. In the case of Eof4, a small significant warming SST close to the northern coast of the Gulf of Guinea led to evaporation in this region. This moisture does not penetrate far into the continent but remains localized in coastal countries of West Africa.

This study indicates that ocean-atmosphere processes can be used to improve the forecasting of extreme rainfall episodes over West Africa and could increase our warning capacity for severe weather conditions in that region. Coupled model simulations could then give one useful dynamical basis for such ocean-atmosphere processes. Such initiatives are encouraged to better explain the extreme rainfall phenomena. It could also help in planning the risks associated with these climate hazards, particularly on water resources management and civil defense.

\section{Competing Interests}

The authors declare that there are no competing interests regarding the publication of this paper.

\section{Acknowledgments}

The authors thank the "Laboratoire Mixte International ECLAIRS” for its financial support. They are grateful to Dr. U. Koffi who helped in improving the English form of the paper. 


\section{References}

[1] Y. K. Kouadio, D. A. Ochou, and J. Servain, “Tropical Atlantic and rainfall variability in Côte d'Ivoire," Geophysical Research Letters, vol. 30, no. 5, 2003.

[2] K. Y. Kouadio, A. Aman, A. D. Ochou, K. E. Ali, and P. A. Assamoi, "Rainfall variability patterns in West Africa: case of cote d'Ivoire and Ghana," Journal of Environmental Science and Engineering, vol. 5, pp. 1229-1238, 2011.

[3] E. L. Molua, "Turning up the heat on African agriculture: the impact of climate change on Cameroon's agriculture," African Journal of Agriculture and Resource Economics, vol. 2, no. 1, 2008.

[4] L. Mouhamed, S. B. Traore, A. Alhassane, and B. Sarr, "Evolution of some observed climate extremes in the West African Sahel," Weather and Climate Extremes, vol. 1, pp. 19-25, 2013.

[5] R. W. Katz and B. G. Brown, "Extreme events in a changing climate: variability is more important than averages," Climatic Change, vol. 21, no. 3, pp. 289-302, 1992.

[6] J. F. B. Mitchell, S. Manabe, V. Meleshko, and T. Tokioka, "Equilibrium climate change and its implications for the future," in Climate Change: The IPCC Scientific Assessment, J. T. Houghton, G. J. Jenkins, and J. J. Ephraums, Eds., pp. 131-172, Cambridge University Press, Cambridge, UK, 1990.

[7] J. P. Lhomme, "Evolution de la pluviométrie annuelle en Côte d'Ivoire au cours des soixante dernières années," La Météorologie, vol. 6, no. 25, pp. 135-140, 1981.

[8] E. Mine and J. M. Bocquet, Safety Rehabilitation Works for the Bagré Dam, Colloque CFBR-SHF: Dimensionnement et Fonctionnement des Évacuateurs de Crues, Lyon, France, 2009.

[9] A. Giannini, S. Salack, T. Lodoun, A. Ali, A. T. Gaye, and O. Ndiaye, "A unifying view of climate change in the Sahel linking intra-seasonal, interannual and longer time scales," Environmental Research Letters, vol. 8, no. 2, Article ID 024010, 2013.

[10] M. New, B. Hewitson, D. B. Stephenson et al., "Evidence of trends in daily climate extremes over southern and west Africa," Journal of Geophysical Research: Atmospheres, vol. 111, no. 14, Article ID D14102, 2006.

[11] B. T. Goula, E. G. Soro, W. Kouassi, and B. Srohourou, "Tendances et ruptures au niveau des pluies journalières extrêmes en Côte d'Ivoire (Afrique de l'Ouest)," Hydrological Sciences Journal, vol. 57, no. 6, pp. 1067-1080, 2012.

[12] J. H. Christiansen, B. Hewitson, A. Busuioc et al., "Regional climate projections Climate Change 2007: the physical science basis," in Contribution of Working Group I to the Fourth Assessment Report of the Intergovernmental Panel on Climate Changed, S. Solomon, D. Qin, M. Manning et al., Eds., Cambridge University Press, Cambridge, UK, 2007.

[13] P. Knippertz and A. H. Fink, "Dry-season precipitation in tropical West Africa and its relation to forcing from the extratropics," Monthly Weather Review, vol. 136, no. 9, pp. 35793596, 2008.

[14] A. A. Abatan, West African extreme daily precipitation in observations and stretched-grid simulations by CAM-EULAG [Graduate thesis], Iowa State University, Ames, Iowa, USA, 2001, paper 10401.

[15] G. Panthou, T. Vischel, T. Lebel, J. Blanchet, G. Quantin, and A. Ali, "Extreme rainfall in West Africa: a regional modeling," Water Resources Research, vol. 48, no. 8, pp. 1-19, 2012.

[16] B. Ibrahim, J. Polcher, H. Karambiri, and B. Rockel, "Characterization of the rainy season in Burkina Faso and it's representation by regional climate models," Climate Dynamics, vol. 39 , no. 6 , pp. 1287-1302, 2012.

[17] S. E. Nicholson and I. M. Palao, "A re-evaluation of rainfall variability in the Sahel. Part I. Characteristics of rainfall fluctuations," International Journal of Climatology, vol. 13, no. 4, pp. 371-389, 1993.

[18] B. Sultan, S. Janicot, and P. Drobinski, "Characterization of the diurnal cycle of the West African Monsoon around the Monsoon Onset," Journal of Climate, vol. 20, no. 15, pp. 40144032, 2007.

[19] A. Diawara, F. Yoroba, K. Y. Kouadio et al., "Climate variability in the Sudano-Guinean transition area and its impact on vegetation: the case of the Lamto region in Côte D'Ivoire," Advances in Meteorology, vol. 2014, Article ID 831414, 11 pages, 2014.

[20] G. J. Huffman, R. F. Adler, M. M. Morrissey et al., "Global precipitation at one-degree daily resolution from multisatellite observations," Journal of Hydrometeorology, vol. 2, no. 1, pp. 3650, 2001.

[21] C. Frei and C. Schär, "Detection probability of trends in rare events: theory and application to heavy precipitation in the Alpine region," Journal of Climate, vol. 14, no. 7, pp. 1568-1584, 2001.

[22] P. D. Jones, E. B. Horton, C. K. Folland, M. Hulme, D. E. Parker, and T. A. Basnett, "The use of indices to identify changes in climatic extremes," Climatic Change, vol. 42, no. 1, pp. 131-149, 1999.

[23] A. M. G. Klein Tank and G. P. Können, "Trends in indices of daily temperature and precipitation extremes in Europe, 194699," Journal of Climate, vol. 16, no. 22, pp. 3665-3680, 2003.

[24] N. Plummer, M. J. Salinger, N. Nicholls et al., "Changes in climate extremes over the Australian region and New Zealand during the twentieth century," Climatic Change, vol. 42, no. 1, pp. 183-202, 1999.

[25] M. J. Manton, P. M. Della-Marta, M. R. Haylock et al., "Trends in extreme daily rainfall and temperature in southeast Asia and the south Pacific: 1961-1998," International Journal of Climatology, vol. 21, no. 3, pp. 269-284, 2001.

[26] B. Sarr and I. Lona, "Les fortes pluies enregistrées au Sahel au cours de l'hivernage 2007: variabilité et/ou changement climatique," Communication Personnel, Centre Régional Agrhymet, Département Formation et Recherche, Niamey, Niger, 2007.

[27] R. W. Reynolds, N. A. Rayner, T. M. Smith, D. C. Stokes, and W. Wang, "An improved in situ and satellite SST analysis for climate," Journal of Climate, vol. 15, no. 13, pp. 1609-1625, 2002.

[28] E. Kalnay, M. Kanamitsu, R. Kistler et al., "The NCEP/NCAR 40-year reanalysis project," Bulletin of the American Meteorological Society, vol. 77, no. 3, pp. 437-471, 1996.

[29] S. E. Nicholson, "Rainfall and atmospheric circulation during drought periods and wetter years in West Africa," Monthly Weather Review, vol. 109, no. 10, pp. 2191-2208, 1981.

[30] V. Mathon, H. Laurent, and T. Lebel, "Mesoscale convective system rainfall in the Sahel," Journal of Applied Meteorology, vol. 41, no. 11, pp. 1081-1092, 2002.

[31] M. Widmann and C. Schär, "A principal component and long-term trend analysis of daily precipitation in Switzerland," International Journal of Climatology, vol. 17, no. 12, pp. 13331356, 1997.

[32] J. Servain and D. Legler, "Empirical orthogonal functions analyses of tropical Atlantic Sea surface temperature and wind stress: 1964-1979," Journal of Geophysical Research, vol. 91, no. 12, pp. 14181-14191, 1986. 
[33] P. Tschakert, R. Sagoe, G. Ofori-Darko, and S. N. Codjoe, "Floods in the Sahel: an analysis of anomalies, memory, and anticipatory learning," Climatic Change, vol. 103, no. 3, pp. 471502, 2010.

[34] L. Le Barbé and T. Lebel, "Rainfall climatology of the HAPEXSahel region during the years 1950-1990," Journal of Hydrology, vol. 188-189, pp. 43-73, 1997.

[35] T. Lebel, A. Diedhou, and H. Laurent, "Seasonal cycle and interannual variability of the Sahelian rainfall at hydrological scales," Journal of Geophysical Research, vol. 108, no. 8, 2003.

[36] F. C. Okorie, I. Okeke, A. Nnaji, C. Chibo, and E. Pat-Mbano, "Evidence of climate variability in Imo state of Southeastern Nigeria," Journal of Earth Science and Engineering, vol. 2, no. 2012, pp. 544-553, 2012.

[37] C. McSweeney, M. New, and G. Lizcano, "UNDP climate change country profiles liberia," Tech. Rep., 2013, http://ncsp.undp.org/ document/undp-climate-change-country-profile-liberia.

[38] K. E. Ali, K. Y. Kouadio, E.-P. Zahiri, A. Aman, A. P. Assamoi, and B. Bourles, "Influence of the Gulf of Guinea coastal and equatorial upwellings on the precipitations along its northern coasts during the boreal summer period," Asian Journal of Applied Sciences, vol. 4, no. 3, pp. 271-285, 2011.

[39] B. Liebmann, R. M. Dole, C. Jones, I. Bladé, and D. Allured, "Influence of choice of time period on global surface temperature trend estimates," Bulletin of the American Meteorological Society, vol. 91, no. 11, pp. 1485-1491, 2010.

[40] S. E. Nicholson and D. Entekhabi, "The quasi-periodic behavior of rainfall variability in Africa and its relationship to the southern oscillation," Archives for Meteorology, Geophysics, and Bioclimatology, Series A, vol. 34, no. 3-4, pp. 311-348, 1986.

[41] A. Diedhiou, S. Janicot, A. Viltard, and P. De Felice, "Evidence of two regimes of easterly waves over West Africa and the tropical Atlantic," Geophysical Research Letters, vol. 25, no. 15, pp. 28052808, 1998.

[42] A. Diedhiou, S. Janicot, A. Viltard, P. De Felice, and H. Laurent, "Easterly wave regimes and associated convection over West Africa and tropical Atlantic: results from the NCEP/NCAR and ECMWF reanalyses," Climate Dynamics, vol. 15, no. 11, pp. 795$822,1999$.

[43] G. Caniaux, H. Giordani, J.-L. Redelsperger, F. Guichard, E. Key, and M. Wade, "Coupling between the Atlantic cold tongue and the West African monsoon in boreal spring and summer," Journal of Geophysical Research: Oceans, vol. 116, no. 4, Article ID C04003, 2011.

[44] H. L. Li, H. J. Wang, and Y. Z. Yin, "Interdecadal variation of the West African summer monsoon during 1979-2010 and associated variability," Climate Dynamics, vol. 39, no. 12, pp. 28832894, 2012. 

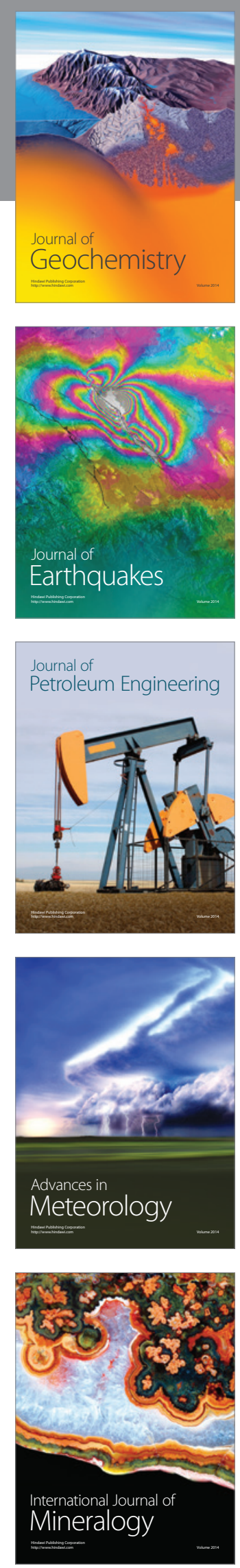
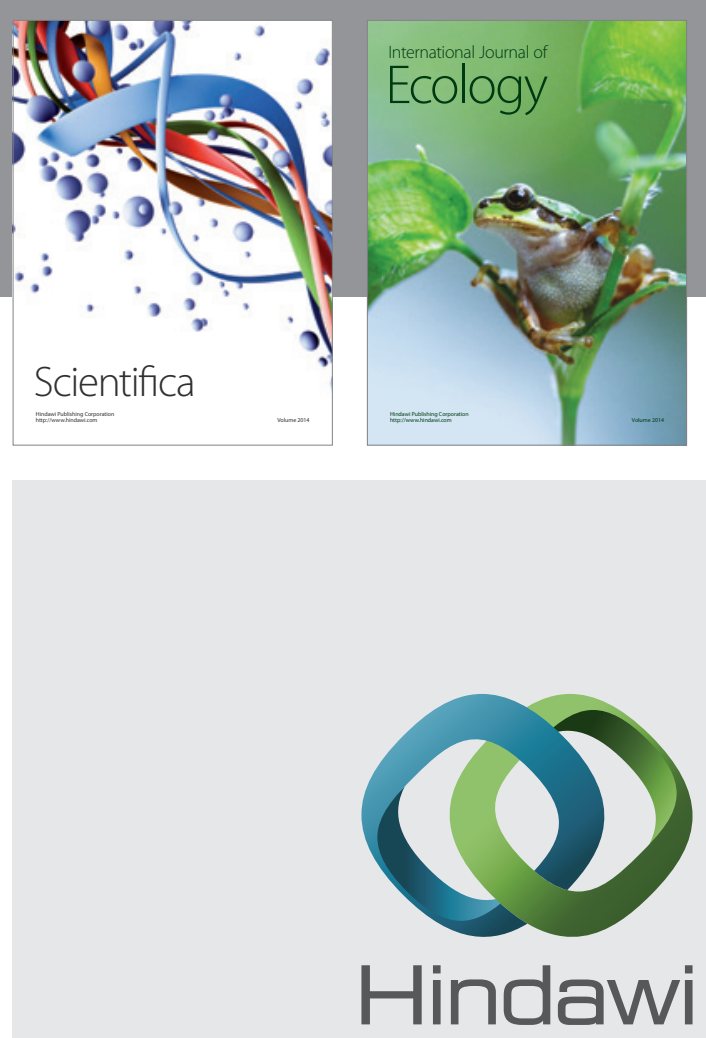

Submit your manuscripts at

http://www.hindawi.com
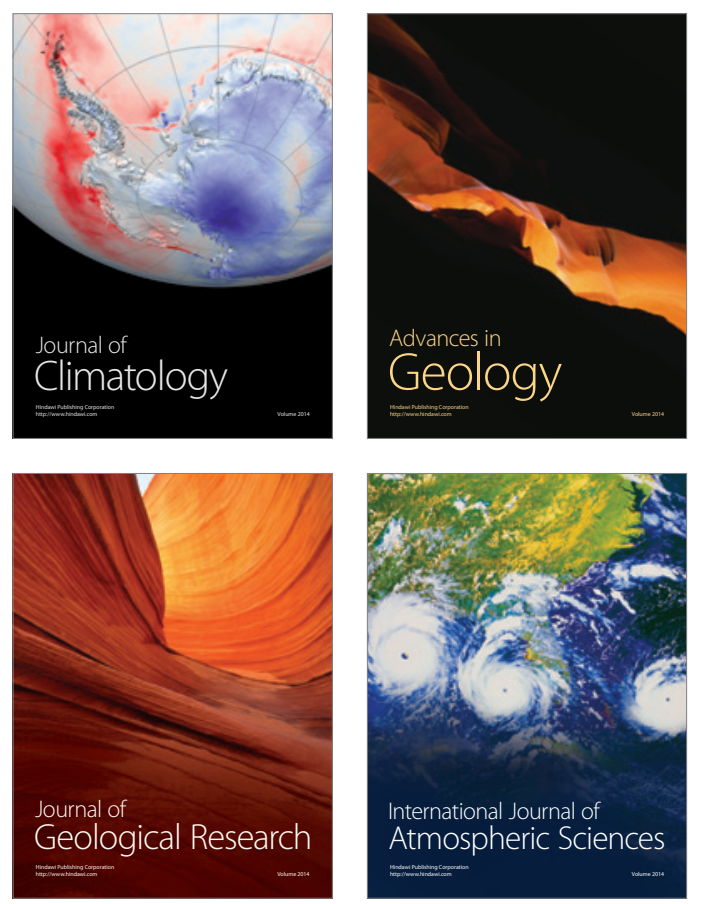

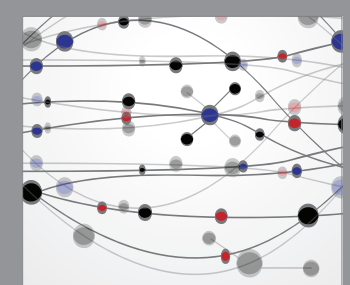

The Scientific

\section{World Journal}
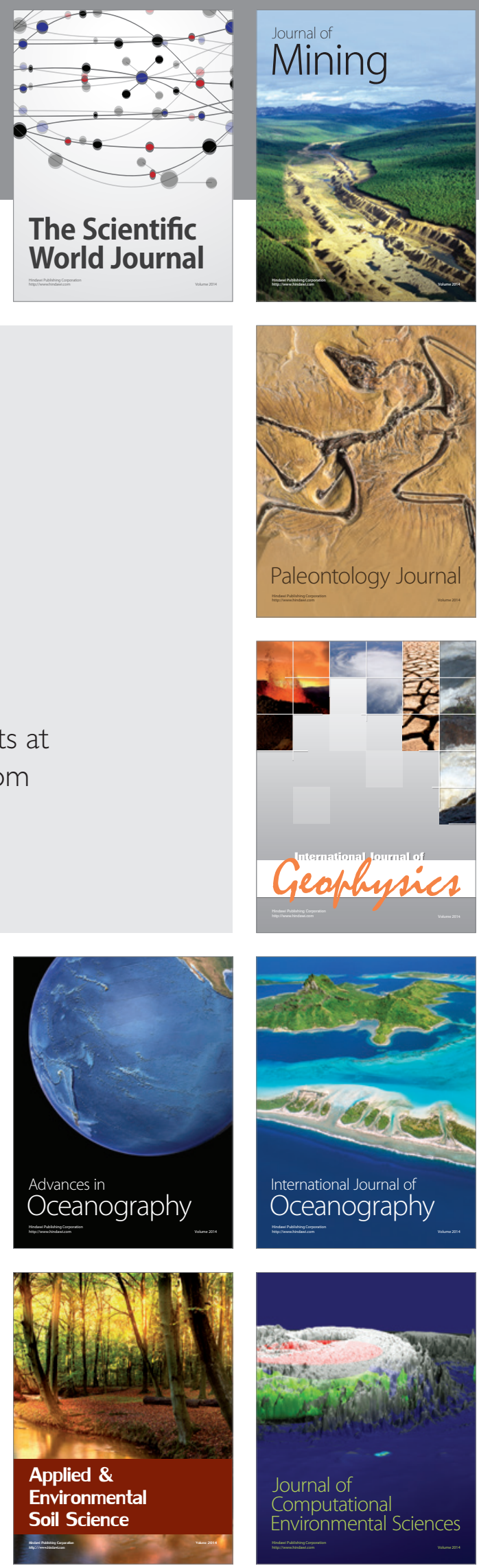